\title{
Disrupted Neuroglial Metabolic Coupling after Peripheral Surgery
}

\author{
Teresa Femenía, ${ }^{1,2}$ Alfredo Giménez-Cassina, ${ }^{3,4}$ @Simone Codeluppi, ${ }^{1,3}$ Teresa Fernández-Zafra, ${ }^{1}$ \\ 국ika Katsu-Jiménez, ${ }^{3}$-Niccolò Terrando, ${ }^{5,6}$ Lars I. Eriksson, ${ }^{1,2}$ and Marta Gómez-Galán ${ }^{1,2}$ \\ ${ }^{1}$ Department of Physiology and Pharmacology, ${ }^{2}$ Section for Anesthesiology and Intensive Care Medicine, ${ }^{3}$ Department of Medical Biochemistry and \\ Biophysics, Karolinska Institutet, Stockholm, Sweden, ${ }^{4}$ Department of Biología Molecular, Universidad Autónoma de Madrid, Centro de Biología Molecular \\ "Severo Ochoa" (CSIC-UAM), Spain, ${ }^{5}$ Department of Anesthesiology, Basic Science Division, and ${ }^{6}$ Center for Translational Pain Medicine, Duke University \\ Medical Center, Durham, North Carolina 27710
}

Immune-related events in the periphery can remotely affect brain function, contributing to neurodegenerative processes and cognitive decline. In mice, peripheral surgery induces a systemic inflammatory response associated with changes in hippocampal synaptic plasticity and transient cognitive decline, however, the underlying mechanisms remain unknown. Here we investigated the effect of peripheral surgery on neuronal-glial function within hippocampal neuronal circuits of relevance to cognitive processing in male mice at 6,24, and $72 \mathrm{~h}$ postsurgery. At $6 \mathrm{~h}$ we detect the proinflammatory cytokine IL- 6 in the hippocampus, followed up by alterations in the mRNA and protein expression of astrocytic and neuronal proteins necessary for optimal energy supply to the brain and for the reuptake and recycling of glutamate in the synapse. Similarly, at $24 \mathrm{~h}$ postsurgery the mRNA expression of structural proteins (GFAP and AQP4) was compromised. At this time point, functional analysis in astrocytes revealed a decrease in resting calcium signaling. Examination of neuronal activity by whole-cell patch-clamp shows elevated levels of glutamatergic transmission and changes in AMPA receptor subunit composition at $72 \mathrm{~h}$ postsurgery. Finally, lactate, an essential energy substrate produced by astrocytes and critical for memory formation, decreases at 6 and $72 \mathrm{~h}$ after surgery. Based on temporal parallels with our previous studies, we propose that the previously reported cognitive decline observed at $72 \mathrm{~h}$ postsurgery in mice might be the consequence of temporal hippocampal metabolic, structural, and functional changes in astrocytes that lead to a disruption of the neuroglial metabolic coupling and consequently to a neuronal dysfunction.

Key words: astrocytes; calcium imaging; inflammation; neuroglial function; peripheral surgery; $\mathrm{POCD}$

\section{Significance Statement}

A growing body of evidence suggests that surgical trauma launches a systemic inflammatory response that reaches the brain and associates with immune activation and cognitive decline. Understanding the mechanisms by which immune-related events in the periphery can influence brain processes is essential for the development of therapies to prevent or treat postoperative cognitive dysfunction and other forms of cognitive decline related to immune-to-brain communication, such as Alzheimer's and Parkinson's diseases. Here we describe the temporal orchestration of a series of metabolic, structural, and functional changes after aseptic trauma in mice related to astrocytes and later in neurons that emphasize the role of astrocytes as key intermediaries between peripheral immune events, neuronal processing, and potentially cognition.

\section{Introduction}

Despite the classical view of the CNS as an immune privilege organ, growing evidence points to an active crosstalk between the

Received June 27, 2017; revised Nov. 7, 2017; accepted Nov. 10, 2017

Author contributions: T.F., N.T., L.I.E., and M.G.-G. designed research; T.F., A.G.-C., T.F.-Z., Y.K.-J., N.T., and M.G.-G. performed research; T.F., A.G.-C., S.C., and M.G.-G. analyzed data; T.F., L.I.E., and M.G.-G. wrote the paper.

This work was supported by a "Ramón y Cajal” fellowship (RYC-2014-15792 to A.G.-C.) from Spanish “Ministerio de Economía y Competitividad", the Swedish Research Council, the confocal microscope used in the study by Knut and Alice Wallenberg Foundation (Grant KAW2008.0149), and NIH/NIA R01AG057525 to N.T. We thank Anette Ebberyd for excellent technical support, Souren Mkrtchian for critically reading the paper, Lilly Schwieler for assistance with the multiplex cytokine analysis, Enric Domènech-Estévez for the MCT antibodies, and Mia Lindskog for kindly allowing us to use her patch-clamp setup system. peripheral immune system and the CNS, which suggests that immune-related events in the periphery can remotely affect brain function, contributing to neurodegenerative processes and cognitive decline (Perry et al., 2003).

Activation of the peripheral innate immune system after trauma (e.g., surgery) leads to the increase of proinflammatory cytokines in

\footnotetext{
The authors declare no competing financial interests.
}

Correspondence should be addressed to Gómez-Galán Marta; Department of Physiology and Pharmacology, Section for Anesthesiology and Intensive Care Medicine, Karolinska Institutet, Nanna Svart 2, Stockholm, 171 77, Sweden. E-mail: marta.gomez@ki.se.

DOI:10.1523/JNEUROSCI.1797-17.2017

Copyright $\odot 2018$ the authors $\quad 0270-6474 / 18 / 380452-13 \$ 15.00 / 0$ 
both the systemic circulation and the CNS. Importantly, this increase in cytokines has been associated with prolonged impairment in learning and memory (Buvanendran et al., 2006; Beloosesky et al., 2007; Kline et al., 2016).

Recently, the first PET study of the human brain immune activity after surgery using PBR28, a novel translocator protein (TSPO) ligand, revealed a profound postoperative dysregulation of brain glial activity even at 3-4 months after surgery associated with poor cognitive outcome (Forsberg et al., 2017). In surgical rodent models, such a periphery-to-brain inflammatory pathway seems critically dependent on NF-kB and proinflammatory cytokine signaling [e.g., tumor necrosis factor-a (TNF-a)], associated with a transient disruption of blood-brain barrier (BBB) integrity, migration of peripheral macrophages into the hippocampus, and subsequent cognitive impairment (Terrando et al., 2010, 2011; Degos et al., 2013; Yang et al., 2017). However, the consequence of this periphery-to-brain signaling on hippocampal function remains largely unknown. We recently demonstrated that surgery-induced cognitive decline in mice was associated with hippocampal astrocytic morphology alteration and synaptic plasticity impairment. Notably, the astrocytic change preceded the neuronal impairment (Terrando et al., 2013), suggesting that primary changes in astrocyte function have the potential to modulate large-scale neuronal functional systems. With its typical location having one part of the cell attached to the vascular wall and the other part in close proximity to the synapse, astrocytes emerge as pivotal mediators between the periphery and neuronal functions. However, the effects of systemic immune activation and inflammation on astrocyte functions are not well defined.

In the last decade, a large body of evidence suggests that an array of systemic challenges (including surgery) can promote a systemic inflammatory response that may contribute to the exacerbation of acute symptoms of chronic neurodegenerative disease, such as Alzheimer's disease (AD) and Parkinson's disease $(\mathrm{PD})$, thus accelerating disease progression (Perry et al., 2007; Collins et al., 2012). Indeed, a series of disease-generating mechanisms observed after peripheral trauma have also been described on these and other brain disorders associated with cognitive dysfunction, such as $\mathrm{BBB}$ disruption and infiltration of activated macrophages (Lebson et al., 2010; Birch et al., 2014; Perry and Holmes, 2014).

To further understand the temporal pattern of immune activation and simultaneous changes in synaptic transmission within hippocampal neuronal circuits of relevance for cognitive processing, we investigated the effect of surgery on neuronal-glial function combining calcium $\left(\mathrm{Ca}^{2+}\right)$ imaging in astrocytes and whole-cell patch-clamp in CA1 pyramidal cells with structural and metabolic analysis in mice. Our findings uncover a role for astrocytes as mediators between systemic immune and inflammatory events and synaptic neuronal functions including a dysregulation of brain energy metabolism, which may be in turn related to the surgical phenotype, including cognitive impairment postsurgery.

\section{Materials and Methods}

\section{Animals}

All experiments were approved by the Local Ethics Committee for Animal Research at Karolinska Institutet (Stockholm, Sweden) and comply with the Society for Neuroscience policy on the use of animals in research. Male, 12-14 weeks old C57BL6 (Charles River Laboratories) and $\mathrm{CX} 3 \mathrm{CR} 11^{\mathrm{GFP} /+} \mathrm{CCR} 2^{\mathrm{RFP} /+}$ mice [generated as previously described (Saederup et al., 2010) and kindly donated by K. Akassoglou, J. David Gladstone Institutes, San Francisco, California] were used. Mice were housed six per cage under temperature- and humidity-controlled conditions in a
$12 \mathrm{~h}$ light/dark cycle and fed standard rodent chow and water ad libitum. All animals were weighed just before surgery (or saline injection in the case of the naive animals) and before brain collection.

\section{Surgery}

The open stabilized tibia fracture model was performed as previously described (Terrando et al., 2013). Briefly, under isoflurane anesthesia (2.1\% inspired concentration in $0.30 \mathrm{FiO}_{2}$ ) and analgesia (buprenorphine, $0.1 \mathrm{mg} / \mathrm{kg}$, s.c.) a longitudinal incision was made on the left hindpaw and the muscles disassociated. A $0.38 \mathrm{~mm}$ stainless steel pin was then inserted in the intramedullary canal and the osteotomy was performed. The wound was irrigated, sutured with 6-0 Prolene, and the mice were allowed to recover in a warm box before returning to the home cage. The procedure lasted $21 \pm 0.5 \mathrm{~min}$. Temperature was monitored and maintained at $37^{\circ} \mathrm{C}$ with the aid of a warming pad and temperature controlled lights (Harvard Apparatus). Animals killed at $24-72 \mathrm{~h}$ postsurgery received a daily dose of analgesia (buprenorphine, $0.1 \mathrm{mg} / \mathrm{kg}$, s.c.) during the length of the study. Control mice received an equal volume of saline (s.c.).

\section{Acute brain slices}

Mice were terminated at 6, 24, and $72 \mathrm{~h}$ after tibia fracture completion by cervical dislocation. The brain was quickly harvested following decapitation and the whole hippocampus removed into ice-cold oxygenated $\left(95 \% \mathrm{O}_{2}\right.$ and $5 \% \mathrm{CO}_{2}$ ) artificial CSF solution (aCSF) containing the following (in mM): $130 \mathrm{NaCl}, 3.5 \mathrm{KCl}, 1.25 \mathrm{NaH}_{2} \mathrm{PO}_{4}, 24 \mathrm{NaHCO}_{3}$, $2 \mathrm{CaCl}_{2}, 1.5 \mathrm{MgCl}_{2}$, and 10 glucose, pH 7.4 (330 mOsmol). Horizontal hippocampal slices $(400 \mu \mathrm{m})$ were prepared with a vibratome (VT1200S, Leica), and the slices were incubated for $20 \mathrm{~min}$ in an interface chamber containing oxygenated aCSF warmed at $34^{\circ} \mathrm{C}$ and then left for $\sim 40 \mathrm{~min}$ at room temperature.

\section{$\mathrm{Ca}^{2+}$ imaging}

Mouse brain slices were prepared as described previously. After recovering, slices containing the hippocampus were transferred to a customized loading chamber: a millicell culture insert for organotypical cultures (Millicell, Merk-Millipore) fitted in a $35 \mathrm{~mm}$ Petri dish and placed into a $100 \mathrm{~mm}$ Petri dish with bubbling tubing glued around it and a lid with a gas entrance to allow continuous oxygenation $\left(95 \% \mathrm{O}_{2}\right.$ and $\left.5 \% \mathrm{CO}_{2}\right)$. Both the 35 and $100 \mathrm{~mm}$ Petri dishes were filled with regular aCSF (1150 $\mu \mathrm{l}$ and $5 \mathrm{ml}$, approximately).

Loading and mounting. To identify hippocampal astrocytes, slices were first loaded with sulforhodamine 101 (S101) for $15 \mathrm{~min}$, washed and loaded with the $\mathrm{Ca}^{2+}$ indicator dye Oregon Green 488 BAPTA-1 AM (OGB-1;50 $\mu \mathrm{g}$ ) previously dissolved in a solution containing the following: $9 \mu \mathrm{l}$ 0.5\% Cremophor EL (in DMSO) $+1 \mu$ l Pluronic F127 (in DMSO $)+10 \mu$ l regular aCSF (20 $\mu$ M OGB-1; $0.002 \mu \mathrm{M}$ Cremophor EL; $0.01 \%$ Pluronic F127; 0.5\% DMSO). A $5 \mu \mathrm{l}$ drop of the OGB-1 dye solution was placed on top of each individual slice and incubated for $45-60 \mathrm{~min}$ at $37^{\circ} \mathrm{C}$. After that period, the aCSF was replaced for fresh $\mathrm{aCSF}$ and the slices recovered for $30 \mathrm{~min}$ at room temperature. For $\mathrm{Ca}^{2+}$ imaging, slices were mounted upside-down in bottom glass culture dishes (MatTek) precoated with polyethylenimine ( $1 \mathrm{ml}$ for $1 \mathrm{~h}$ at room temperature and rinsed three to five times with distilled water and aCSF). To avoid possible detachment during imaging, the borders of the slices were carefully dried with the help of a filter paper and the slice gently covered with $1 \mathrm{ml}$ of aCSF. Once mounted, the slices were kept in the oxygenated chamber before being transferred individually to the recording chamber (Warner Instruments).

Imaging. Slices were continuously perfused with aCSF at room temperature and astrocytes were identified in the CA1 area with a $25 \times$ objective in an upright laser-scanning confocal microscopy (LSM 710, Carl Zeiss). $S 101$ was excited at $568 \mathrm{~nm}$ and collected through a 630 long-pass filter, whereas OGB-1 was excited at $488 \mathrm{~nm}$ and collected through a $522 \pm 16 \mathrm{~nm}$ bandpass filter.

Spontaneous astrocytic $\mathrm{Ca}^{2+}$ transients were recorded from live hippocampal astrocytes loaded with both OGB-1 and S101 in time-series images of 300-600 frames collected at $1 \mathrm{~s}$ intervals. At the end of the experiments, ATP (100 nM) was applied to monitor typical calcium re- 
sponses of astrocytes. The slices that did not respond to ATP were excluded for the analysis.

The acquired image stacks were registered using the turboreg plugin (Thévenaz et al., 1998) of Fiji (RRID:SCR_002285; Schindelin et al., 2012). The cells were then identified as connected components of the binary images after semiautomated thresholding and size filtering of the SR101 immunofluorescence. The signal intensity of OGB-1AM in each cell was quantified and exported from Fiji (RRID:SCR_002285) to be further processed using a custom python script. The fluorescence signal was converted in $d F / F 0$ where $F 0$ was the mean fluorescence signal of the trace, and all the peaks in the trace were labeled. A response was defined as a peak with $d F / F 0>10 \%$ of $F 0$.

\section{Electrophysiology}

For whole-cell voltage-clamp recordings of CA1 pyramidal cells, after slice recovery, a single slice was transferred to a submersion recording chamber, where it was continuously perfused $(1.8-2 \mathrm{ml} / \mathrm{min})$ with regular aCSF warmed to $31-32^{\circ} \mathrm{C}$. Patch electrodes $(4-6 \mathrm{M} \Omega)$ were filled with a solution containing the following (in mM): 110 (for EPSCs) or 20 (for IPSCs) K-gluconate, 10 (for EPSCs) or 100 (for IPSCs) $\mathrm{KCl}, 4 \mathrm{Mg}_{2}-$ ATP, 10 phosphocreatine, $0.3 \mathrm{Na}_{2}$-GTP, and 10 HEPES, pH 7.3 with $\mathrm{KOH}(270-290 \mathrm{mOsm})$. Cells were voltage-clamped at $-65 \mathrm{mV}$, and either spontaneous EPSCs or IPSCs were recorded using a MultiClamp 700B amplifier (Molecular Devices). The data were acquired using pCLAMP 10 (Molecular Devices). Recordings with a membrane potential $\left(V_{\mathrm{m}}\right)$ more positive than $-55 \mathrm{mV}$ and/or access resistances $(R \mathrm{~s})>30$ $\mathrm{M} \Omega$ were excluded, and only cells with stable $R$ s and $V_{\mathrm{m}}$ (i.e., a change of $<10 \%$ ) were included in the analysis. All PSCs were analyzed using Mini Analysis software (Synaptosoft). Detection criteria included EPSCs and IPSCs with an amplitude $>7.5 \mathrm{pA}$ and a $20-80 \%$ decay-rise time $>0$. Data represent the average of $3 \mathrm{~min}$ of recording. The numerical values are expressed as the mean \pm SEM and $n$ indicates the number of neurons tested.

\section{Brain collection}

Animals were cardially perfused with cold PBS $(20 \mathrm{ml})$ and the hippocampus dissected, wet weighted in lock-safe tubes, and stored at $-80^{\circ} \mathrm{C}$ until further analysis.

\section{Preparation of brain tissue for cytokine analysis}

Hippocampal samples from cold PBS cardially perfused animals were homogenized in ice-cold lysis buffer $(100 \mathrm{mg} / \mathrm{ml})$ containing the following (in mm): $150 \mathrm{NaCl}, 20$ Tris, pH 7.5, 1 EDTA, 1 EGTA, $1 \%$ Triton X-100, protease inhibitor (Roche; Sigma-Aldrich), Phosphatase Inhibitor Cocktail 3 (Sigma-Aldrich), Phosphatase Inhibitor 2 (SigmaAldrich), and $200 \mu \mathrm{l} \mathrm{NaF}$ (from $0.5 \mathrm{M}$ stock), with glass beads for 3-5 min with speed 8 at $4^{\circ} \mathrm{C}$ using a Bullet-Blender (Next Advance). Homogenates were then centrifuged at $14,000 \mathrm{rpm}$ for $10 \mathrm{~min}$ at $4^{\circ} \mathrm{C}$. Cytokines were directly analyzed the same day following the multiplex cytokine assay protocol (see below).

\section{Multiplex cytokine assay}

Brain proinflammatory and anti-inflammatory cytokine levels were determined with Mouse Proinflammatory 10 Plex Ultrasensitive Plate [(IFN- $\gamma$, IL-1 $\beta$, IL-2, IL-4, IL-5, IL-6, IL-10, IL-12 p70, KC/GRO (CXCL1), and TNF- $\alpha$ ] from Meso Scale Discovery at $6-72 \mathrm{~h}$ after tibia fracture completion according to the manufacturer's instructions.

\section{Western blot}

Hippocampal samples were homogenized in 1\% SDS buffer containing protease and phosphate inhibitors (Sigma-Aldrich). Protein concentration was determined using the BCA Protein Assay Kit (Thermo Scientific) and equal amounts of protein $(20-30 \mu \mathrm{g})$ were resolved by SDS-PAGE and transferred onto a PVDF membrane (Invitrogen). Detection was done by enhanced chemiluminescence with ECL Western blotting detection reagents (GE Healthcare). Chemiluminescence was determined with a ChemiDoc MO analyzer (Bio-Rad). Band intensities were quantified by densitometry using ImageJ software (NIH). Ponceau $\mathrm{S}$ staining of the membrane was used as a loading control (Romero-Calvo et al., 2010). Primary antibodies were rabbit monoclonal anti-glutamate
Receptor 1 (AMPA subtype; 1:1000; Abcam, catalog \#ab109450; RRID: AB_10860361); rabbit polyclonal anti-glutamate Receptor 2 (1:1000; Abcam, catalog \#ab20673; RRID:AB_2232655); rabbit polyclonal antiEAAT1 (GLAST; 1:5000; Abcam, catalog \#ab416; RRID:AB_304334); rabbit polyclonal anti-EAAT2 (GLT-1; 1:5000; Abcam, catalog \#ab41621; RRID:AB_941782); rabbit polyclonal anti-glutaminase (1:1000; Abcam, catalog \#ab93434; RRID:AB_10561964); rabbit monoclonal antiglutamine synthetase (1:1000; Abcam, AB176562); rabbit monoclonal anti-glucose transporter GLUT3 (1:5000; Abcam, AB191071), rabbit monoclonal anti-glucose transporter GLUT1 (1:50,000; Abcam, catalog \#ab115730; RRID:AB_10903230); rabbit polyclonal anti-MCT1 (1:500; Santa Cruz Biotechnology, catalog \#sc-50325; RRID:AB_2083632); goat polyclonal anti-MCT2 (1:500; Santa Cruz Biotechnologycatalog \#sc14926; RRID:AB_2187245); rabbit polyclonal anti-MCT4 (1:500; Santa Cruz Biotechnology, catalog \#sc-50329; RRID:AB_2189333).

\section{Quantitative real-time PCR analysis}

The hippocampus was rapidly dissected on ice and frozen on dry ice and stored at $-80^{\circ} \mathrm{C}$ until used. Total RNA was isolated using Isol-RNA lysis reagent (5 PRIME) according to the manufacturer's instructions, and quantified by spectrophotometry using a NanoDrop ND-1000 Spectrophotometer (ThermoFisher Scientific). cDNA synthesis was performed first completing a DNase digestion step for removal of genomic DNA (Invitrogen; $1 \mathrm{U}$ per $1 \mu \mathrm{g}$ of RNA), thereafter first-strand cDNA was performed with equal amounts of total RNA $(1 \mu \mathrm{g} / 20 \mu \mathrm{l}$ reaction $)$ using the iScript cDNA synthesis kit (Bio-Rad) according to the manufacturer's instructions and diluted with nuclease free water up to $100 \mu \mathrm{l}$ after reaction and stored at $-20^{\circ} \mathrm{C}$ until used. A total volume of $2 \mu \mathrm{l}$ (housekeeping) $3 \mu \mathrm{l}$ (rest of the genes) or $6 \mu$ l (cytokines) was used for gene expression analyses, together with $10 \mu$ l SYBR Select Master Mix (Applied Biosystems), $0.5 \mu \mathrm{M}$ of each primer and nuclease free water up to a reaction volume of $20 \mu$ l. Taq-man predesigned probes and TaqMan Fast Advanced Master Mix were used for glucose transporters (Glut1 and Glut3) as well for the housekeeping TATA-box binding protein (Tbp; ThermoFisher Scientific) and prepared following the manufacturer's instructions. Real-time PCR was performed using the iCycler Real-Time PCR Detection System (Applied Biosystems). The sequences of the used primers are listed bellow ( $\mathrm{F}$, forward; $\mathrm{R}$, reverse):

Mct1 F_aatgctgccetgtcctccta, Mct1 R_cccagtacgtgtatttgtagtctccat;

Mct2 F_cagcaacagcgtgatagagct, Mct2 R_tggttgcaggttgaatgctaa;

Mct4 F_cagctttgccatgttcttca, Mct4 R_agccatgagcacctcaaact;

Gfap F_ggggcaaaagcaccaaagaag, Gfap gggacaacttgtattgtgagcc;

Aqp4 F_gagtcaccacggttcatgga, Aqp4 R_cgtttggaatcacagctggc;

Gs F_tgaacaaaggcatcaagcaaatg, Gs R_cagtccagggtacgggtctt;

Gls F_gctgtgctctattgaagtgaca, Gls R_ttgggcagaaaccaccattag;

Actin F_gatgtatgaaggctttggtc, Actin R_tgtgcacttttattggtctc

Slc2a1 (Glut1) TaqMan probe Mm 00441480_m1; Slc2a3 (Glut3) TaqMan probe Mm 00441480_m1.; Tbp TaqMan probe Mm00446973_m1.

The housekeeping gene $\beta$-actin or Tbp were used as endogenous control for normalization. The data analysis was based on the $2-\Delta \Delta C_{t}$ method. The normalized $\Delta C_{t}$ for each gene was calculated by subtracting the $C_{t}$ of the reference gene actin from the $C_{t}$ of each target gene. Then, the double-delta $C_{t}\left(\Delta \Delta C_{t}\right)$ for each gene was calculated by deducting the average $\Delta C_{t}$ of the target gene of the control group from the $\Delta C_{t}$ of each target gene in the surgery group. The fold-changes of the surgery group compared with the control group were calculated as $2-\Delta \Delta C_{t}$.

\section{Immunohistochemistry}

Mice were killed and perfused with saline followed by $4 \%$ paraformaldehyde in $100 \mathrm{~mm}$ phosphate buffer. Their brains were removed, postfixed in the same fixative overnight $\left(4^{\circ} \mathrm{C}\right)$, and then immersed in $30 \%$ sucrose for $48 \mathrm{~h}$. Brains were then embedded in optimal cutting temperature compound, immediately frozen on dry ice, and stored $\left(-80^{\circ} \mathrm{C}\right)$. Coronal sections ( $25 \mu \mathrm{M}$ thick) were cut on a cryostat, mounted on glass slides using Vectashield antifade mounting media (Vector Laboratories, catalog\# H-1200), blocked for $1 \mathrm{~h}$ with 5\% BSA (Sigma-Aldrich) in PBS containing $0.1 \%$ Triton X-100 (Fisher Scientific), and incubated overnight with an anti-GFAP antibody (1:500; rabbit polyclonal, Dako). Immunofluorescence was performed with AlexaFluor Cy3-labeled anti- 
IL-1 $\beta$

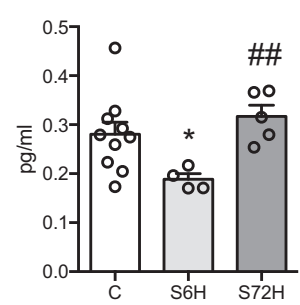

$\mathrm{IL}-10$

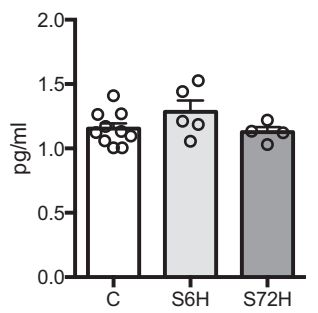

IL-6

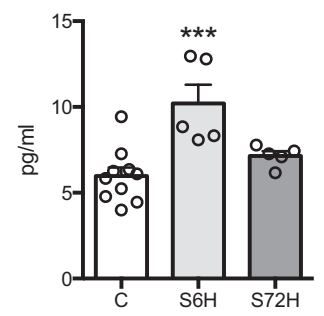

IL-12p70

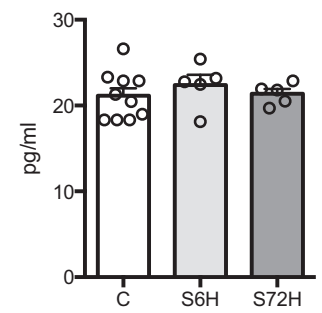

IL-2

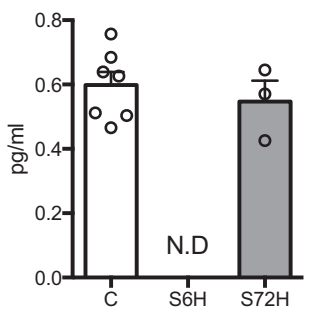

TNF- $\alpha$

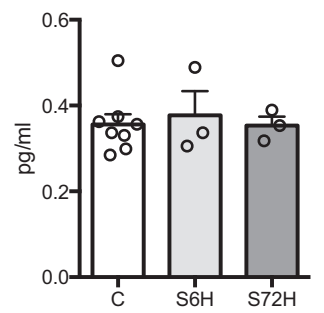

IL-4

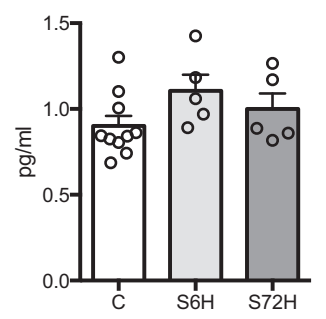

KC/GRO/CXCL1

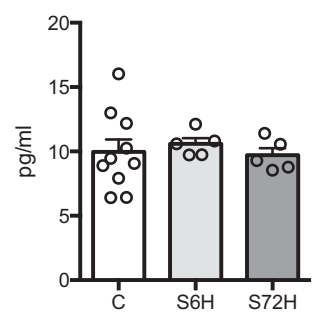

IL-5

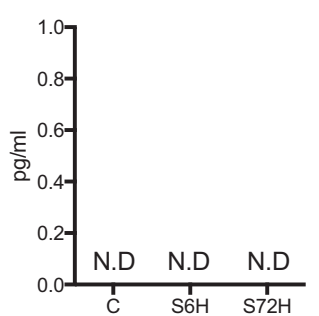

INF- $\gamma$

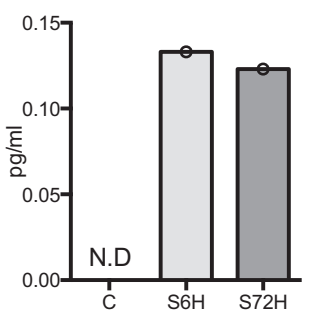

Figure 1. Brain cytokine levels after peripheral surgery. Hippocampal cytokine expression was assessed at 6 and $72 \mathrm{~h}$ postsurgery using a multiplex assay for 10 different cytokines. Whereas the proinflammatory cytokine IL- 6 is increased at $6 \mathrm{~h}$ after surgery $\left({ }^{* * *} p=0.0002\right.$ C vs $\mathrm{S6H}$, $\# p=0.01 \mathrm{~S} 6 \mathrm{H}$ vs S72H; one-way ANOVA, Fisher's multiple-comparison test) IL- $\beta$ is decreased $\left({ }^{*} p=0.03\right.$ ( vs S6H; \#\# $=0.0095$ S6H vs S72H). Empty dots on each graph represent individuals. Initially, numbers of animals were similar for each cytokine $(C: n=10 ; \$ 6 \mathrm{H}: n=5 ; \mathrm{S72H:} n=5)$. However, values that lay below the detectable range were excluded from the analysis. N.D., Nondetectable. All data are presented as the mean \pm SEM.

rabbit DAPI Vectashield solution (Vector Laboratories) to identify cell nuclei. Images were acquired by confocal laser-scanning microscopy (LSM 710 from Carl Zeiss).

\section{Image analyses}

Images of the CA1 region of the hippocampus (left and right) stained for DAPI and GFAP were acquired with an inverted lase- scanning confocal microscope (LSM 800) equipped with a $20 \times / 0.8$ air objective and ZEN2 (blue edition) software (Carl Zeiss). All images were taken using the same intensity settings and the person acquiring the images was blinded to the experimental conditions. Images were acquired using the $z$-stack function, sampling five different depths $1 \mu \mathrm{m}$ apart from the focal center of the tissue. $Z$-stacks images were postprocessed and analyzed with ImageJ software (RRID:SCR_003070).

\section{Lactate}

Approximately 10-25 mg of tissue was homogenized in $1 \mathrm{ml}$ of a dry-ice chilled solution containing $80 \%$ methanol in $\mathrm{H}_{2} \mathrm{O}$. The homogenates were then incubated at $-20^{\circ} \mathrm{C}$ overnight, and they were then centrifuged at $12,000 \mathrm{rpm} \times 15 \mathrm{~min}$ to remove the insoluble fraction. The supernatants, containing soluble metabolites, were then lyophilized and subsequently resuspended in $50 \mu \mathrm{l}$ of sterile $\mathrm{H}_{2} \mathrm{O}$. The amount of lactate present in the supernatants was determined using the LACT reagent from Beckman Coulter, according to the manufacturer's guidelines. The results were then normalized by the starting amount of tissue used to prepare the homogenate.

\section{Experimental design and statistical analysis}

An aseptic orthopedic surgery was performed on male C57BL6 and $\mathrm{CX} 3 \mathrm{CR} 1^{\mathrm{GFP} /+} \mathrm{CCR} 2^{\mathrm{RFP} /+}$ mice under anesthesia and analgesia conditions. On average the total anesthesia time (including the induction time) was $22.2 \pm 1$. min and animals recovered in $\sim 2-5$ min. Experimental groups were randomly divided in three groups and killed by cervical dislocation at three different time points: 6,24 , and $72 \mathrm{~h}$ postsurgery. The 24 and $72 \mathrm{~h}$ group received a daily dose of analgesia to avoid the possible effect of pain on the brain. To avoid experimental variation over time, control animals from the same batch of animals were assigned to each of the groups and received a daily injection of saline (s.c). However, because no statistical difference was found in any of the performed experiments, all controls were pooled as a single group. The number of animals assigned per group was determined from previous experiences in the field and included into the results section for each experiment.
Statistical analyses were performed using Prism v6 software (GraphPad; RRID:SCR_002798). D'agostino and Pearson omnibus normality test was used to test normality of values distribution. Significance of difference was analyzed using unpaired two-tailed Student's $t$ test for single comparisons or ANOVA one-way test analysis followed by Fisher's multiple-comparisons test. In cases of variances that were not assumed to be equal, a Welch correction was performed. Data are presented as mean \pm SEM; $p<0.05$ was considered significant.

\section{Results}

\section{Brain cytokine levels after peripheral surgery}

It has been previously reported that tibia fracture increases both the systemic and hippocampal expression levels of the proinflammatory cytokines, IL- $1 \beta$ and IL- 6 at $6 \mathrm{~h}$ postsurgery (Cibelli et al., 2010; Terrando et al., 2010; Fidalgo et al., 2011; Lu et al., 2015). To further explore the presence of these and other inflammatory cytokines in the brain after tibia fracture, we determined the protein levels of several hippocampal proinflammatory and antiinflammatory cytokine by multiplex analysis (Fig. 1). From all the cytokines tested (IFN- $\gamma$, IL-1 $\beta$, IL-2, IL-4, IL-5, IL-6, IL-10, IL-12 p70, KC/GRO/CXCL1, and TNF- $\alpha$ ) we found an increase in IL- 6 at $6 \mathrm{~h}$ after tibia fracture, returning to control values at $72 \mathrm{~h}$ postsurgery (Fig. $1 B ;{ }^{* * *} p=0.0002 \mathrm{C}$ vs S6H; $\# p=0.01 \mathrm{~S} 6 \mathrm{H}$ vs $\mathrm{S} 72 \mathrm{H}$; one-way ANOVA, Fisher's multiple-comparisons test; $n=5-10$ animals/group). Notably, in opposition to those studies that found increased IL- $1 \beta$ at $6 \mathrm{~h}$ postsurgery (Cibelli et al., 2010; Fidalgo et al., 2011) we did find reduced IL- $1 \beta$ at 6 h postsurgery reversed by $72 \mathrm{~h}$ (Fig. $1 B ;{ }^{\star} p=0.03 \mathrm{C}$ vs S6H; \#\# $p=0.0095 \mathrm{~S} 6 \mathrm{H}$ vs S72H; one-way ANOVA, Fisher's multiple-comparisons test; $n=4-10$ animals/group). Similarly, Rosczyk et al. (2008), comparing adults against aged animals, observed that whereas aged mice showed an increase IL- $1 \beta$ mRNA in the hippocampus after surgical trauma, adult mice showed control values of IL-1 $\beta$ mRNA implying that aging might be a critical factor regarding to the presence of IL- $1 \beta$ after peripheral surgery. 
A

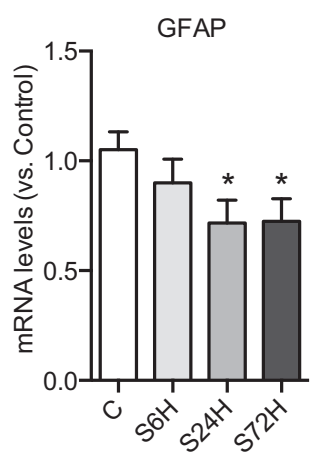

B

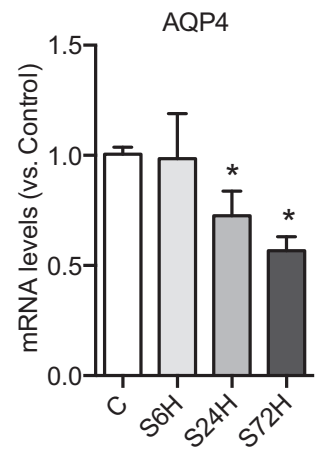

Figure 2. Peripheral surgery regulates expression of astrocytic markers. Analysis of gene expression by qRT PCR of glial cells markers at 6,24 , and $72 \mathrm{~h}$ postsurgery. The astrocytic markers $(\boldsymbol{A})$ GFAP and $(\boldsymbol{B})$ AQP4 are downregulated at 24 and $72 \mathrm{~h}$ postsurgery. (GFAP: ${ }^{*} p=$

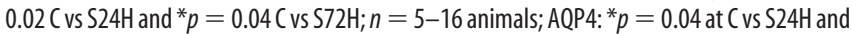
${ }^{*} p=0.01$ ( vs S72 h; $n=4-12$; one-way ANOVA, Fisher's multiple-comparison test). All data are presented as the mean \pm SEM.

Peripheral surgery regulates expression of astrocytic markers Cytokines, including IL-6, can cross the BBB via saturable transport (Banks et al., 1994, 1995; Gutierrez et al., 1994; Banks, 2005) to act directly on astrocytes, microglia and neurons. Previously, we have shown that $24 \mathrm{~h}$ after tibia fracture, hippocampal GFAP ${ }^{+}$ astrocytes from the stratum radiatum are morphologically altered, with astrocytes presenting shorter processes and reduced GFAP coverage. These changes were completely reversed at $72 \mathrm{~h}$ postsurgery (Terrando et al., 2013). Hence, we sought to explore the effect of tibia fracture on the expression of two main astrocytic markers, GFAP and AQP4. Time course studies were performed in hippocampal homogenates from control and surgerytreated animals between 6, 24, and $72 \mathrm{~h}$ following tibia fracture (Fig. 2). Compared with naive animals, the mRNA expression of both GFAP and AQP4 was decreased at 24 and $72 \mathrm{~h}$ postsurgery (Fig. 2; GFAP: ${ }^{\star} p=0.02$ at $24 \mathrm{~h}$ and ${ }^{\star} p=0.04$ at $72 \mathrm{~h} ; n=5-16$ animals; AQP4: ${ }^{*} p=0.04$ at $24 \mathrm{~h}$ and ${ }^{*} p=0.01$ at $72 \mathrm{~h} ; n=4-12$; one-way ANOVA, Fisher's multiple-comparisons test).

\section{Resting $\mathrm{Ca}^{2+}$ signaling is decreased in the hippocampal astrocytic network after surgery}

To evaluate the functional consequences of peripheral surgery on astrocytes we monitored spontaneous intracellular $\mathrm{Ca}^{2+}$ transients in a population of cells loaded with both, the calcium indicator OGB-1 and the astrocytic marker SR101 at $24 \mathrm{~h}$ after tibia fracture (Fig. 3A). This technique allowed us to selectively identify astrocytes among other brain cells (neurons and microglia) because in the hippocampus SR101 is taken up mainly by GFAP ${ }^{+}$ astrocytes (Kafitz et al., 2008). Nevertheless, in recent years some authors suggest that oligodendrocyte labeling may occur through transfer from astrocytes via gap-junction coupling between these two cell populations (Hill and Grutzendler, 2014).

We analyzed the spontaneous $\mathrm{Ca}^{2+}$ activity in 19 and 14 hippocampal slices, from five control and four surgery-treated animals. We first observed that the number of labeled astrocytes $\left(\mathrm{SR} 101^{+}\right.$cells) was significantly reduced in slices from $24 \mathrm{~h}$ surgery-treated animals compared with hippocampal slices from control animals (Fig. $3 D ; 35 \pm 2.6$ vs $49 \pm 3$; ${ }^{* *} p=0.002$; unpaired $t$ test; $n=19-14$ slices). This difference in number might be due to the reduced astrocytic GFAP coverage previously described in these animals (Terrando et al., 2013), which could make the detection of staining more difficult. However, to rule out this possibility, we analyzed the number of $\mathrm{GFAP}^{+}$cells by immunohistochemistry and found no differences compared with control (Fig. $3 E ; p=0.29$; $t$ test; $n=8-10$ animals, unpaired $t$ test). Notably, we found a profound decrease in GFAP immunoreactivity (Fig. $3 F, G ; p=0.0019 ; t$ test; $n=6-9$ animals, unpaired $t$ test), which correlate with the decrease in GFAP expression already described (Fig. 2A).

Next, we analyzed the percentage of active astrocytes per slice. Although the mean of the percentage of active cells did not reach significance (Fig. $3 H ; 5.3 \pm 0.8 \%$ vs $9.9 \pm 2.6 \%$; $p=0.08$, unpaired $t$ test with Welch's correction; $n=19-14$ slices; 7 animals/ group), the comparison of the variance was highly significant $(\# \# \#=0.0001, F$ test to compare variances; $F=10.36$; $D F n=$ 18 ; DFd $=13$ ) indicating different subpopulation of astrocytes among groups. Then, we analyzed the frequency of the $\mathrm{Ca}^{2+}$ events detected during a $5 \mathrm{~min}$ recording sequence, and found that the $\mathrm{Ca}^{2+}$ event frequency was higher in the control group (Fig. $3 I ; 1.5 \pm 0.1$ vs $1.1 \pm 0.07$ events per $5 \mathrm{~min} ;{ }^{\star} p=0.01$; unpaired $t$ test with Welch's correction; $n=19-14$ slices; $4-5$ animals/group). We also recorded the $\mathrm{Ca}^{2+}$ response to ATP $(100 \mathrm{~mm}$ ) during $5 \mathrm{~min}$ of bath application (Fig. 3J). Although the percentage of ATP responders was similar (data not shown; $26.3 \pm 6.1 \%$ vs $22.4 \pm 4.1 \%, \mathrm{C}$ vs S $24 \mathrm{H} ; n=10-15$ slices; $p=$ 0.64 , unpaired $t$ test) the frequency was significantly higher in the control group (Fig. 3J; $2.1 \pm 0.1$ vs $1.7 \pm 0.1$ events per $5 \mathrm{~min}$; ${ }^{*} p=0.05$; unpaired $t$ test with Welch's correction; $n=10-15$ slices; 7 animals/group). Moreover, whereas astrocytes from hippocampal slices of naive animals showed a heterogeneous functional profile with astrocytes able to fire 1-9 spikes/5 min, $\mathrm{Ca}^{2+}$ signals from hippocampal slices of surgery-treated animals did always show a single population of astrocytes firing 1-2 single $\mathrm{Ca}^{2+}$ spikes/5 min. Together these data suggest that peripheral surgery primarily changes the activity pattern among the most active subpopulation of hippocampal astrocytes.

Deficiency of glucose and lactate transporters is accompanied with changes in hippocampal lactate levels after peripheral surgery

A classical role attributed to astrocytes is to ensure an adequate metabolic supply to neurons. Astrocytes take up blood glucose through glucose transporters expressed in their end-feet and metabolize it to lactate, which is then delivered to neurons via lactate transporters to be used as an energy substrate in addition to glucose during high energy demands (Allaman et al., 2011; Fig. 4A). Alterations in the regulation of this metabolic supply to neurons have been shown to have detrimental consequences in higher brain functions, such as cognition (Suzuki et al., 2011).

First, we analyzed the time course for the hippocampal lactate levels between 6, 24, and $72 \mathrm{~h}$ following tibia fracture. Compared with controls, lactate concentration was decreased at 6 and $72 \mathrm{~h}$ after trauma, with normal levels at $24 \mathrm{~h}$ (Fig. $4 B ;{ }^{\star} p=0.01 \mathrm{C}$ vs $\mathrm{S} 6 \mathrm{H} ;{ }^{\star} p=0.047 \mathrm{C}$ vs S72H; $p=0.7 \mathrm{C}$ vs S24H; $n=5$ animals/ group; one-way ANOVA, Fisher's multiple-comparisons test).

Second, we evaluated the expression pattern of the two main glucose transporters in the brain: GLUT-1 (expressed in the astrocytic end-feet) and GLUT-3 (expressed in neurons). Both, Glut- 1 and Glut-3 gene expression was downregulated at $6 \mathrm{~h}$ after trauma (Fig. $4 C$, top; Glut-1: ${ }^{* *} p=0.0031$, S6H vs C; $n=5-15$; Glut-3: ${ }^{* *} p<0.0002$ S6H vs C; $n=5-15$ animals, respectively; one-way ANOVA, Fisher's multiple-comparisons test). Protein levels were decreased at $72 \mathrm{~h}$ after surgery for GLUT-1 (Fig. 4B, bottom, $C ;{ }^{*} p=0.019, \mathrm{~S} 72 \mathrm{H}$ vs $\mathrm{C} ; n=5$ animals/group; one-way ANOVA, Fisher's multiple-comparisons test) and decreased at 24 
A

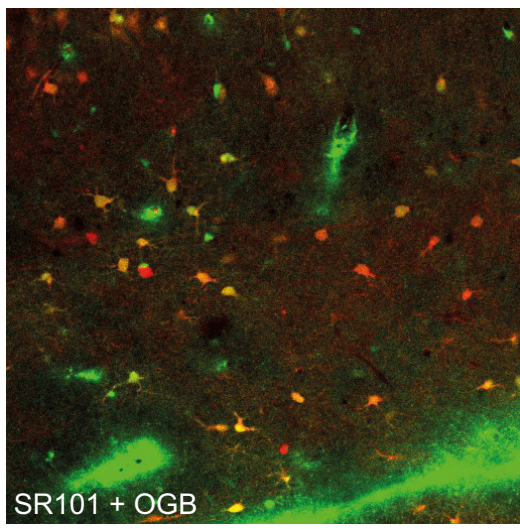

B
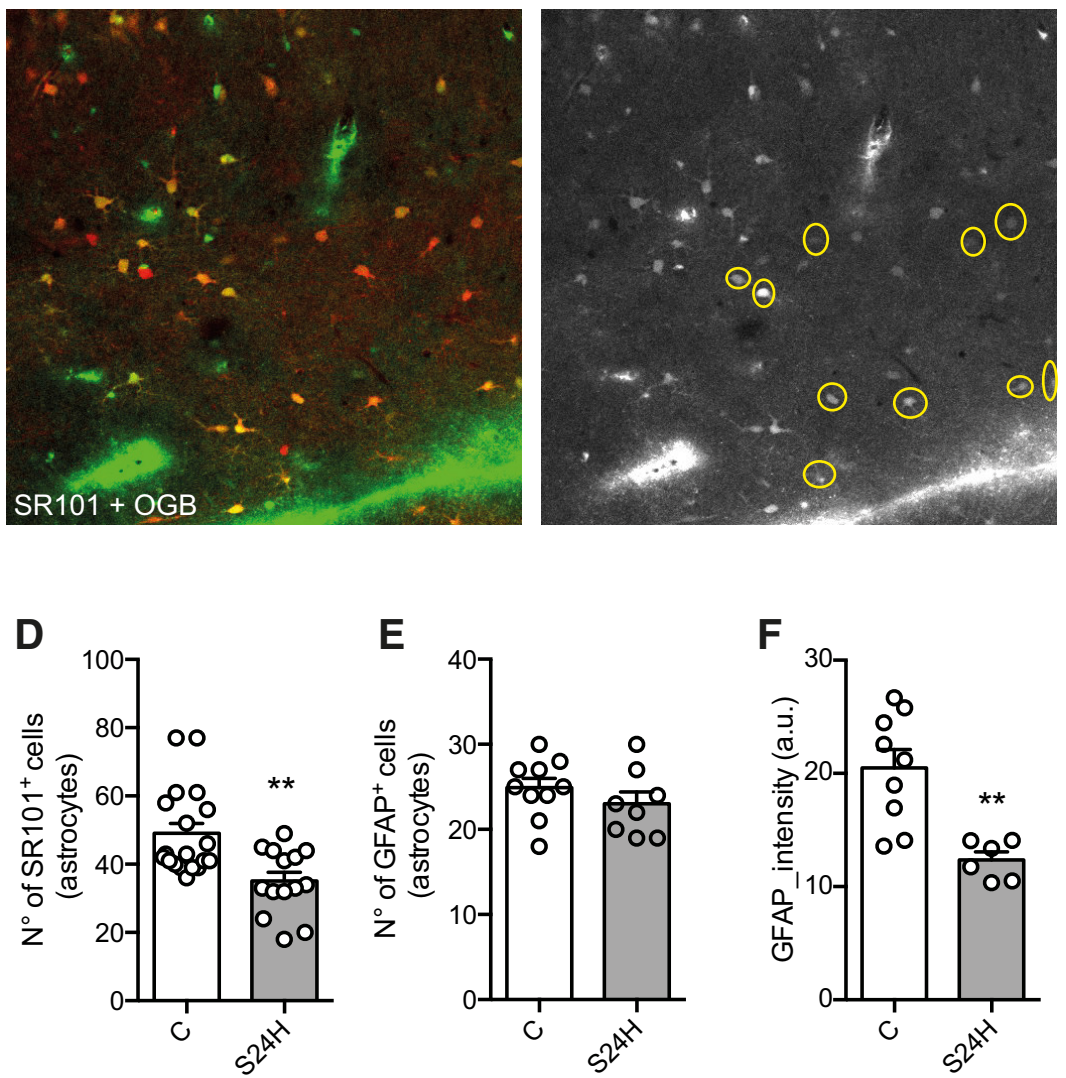

E

H

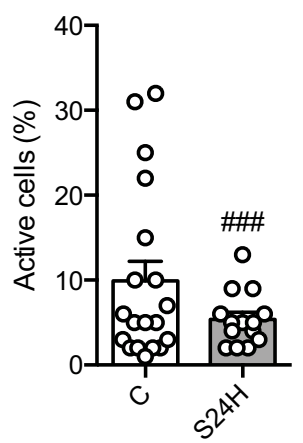

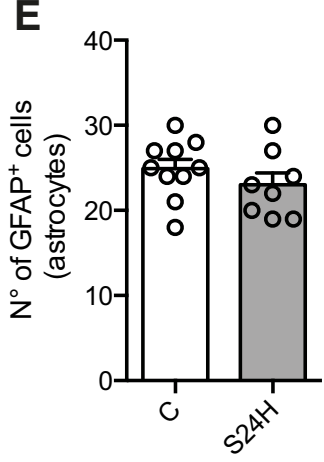

I

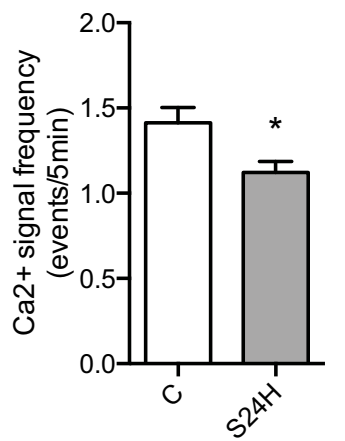

F

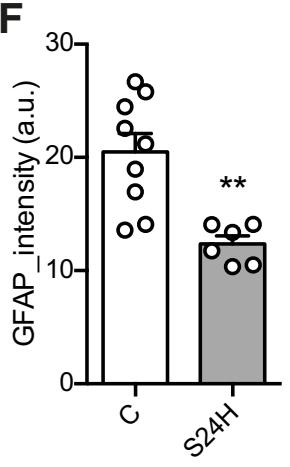

\section{J}

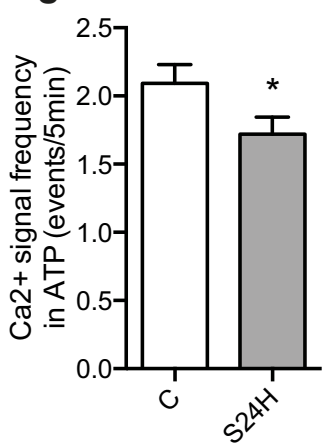

C
Control (C)

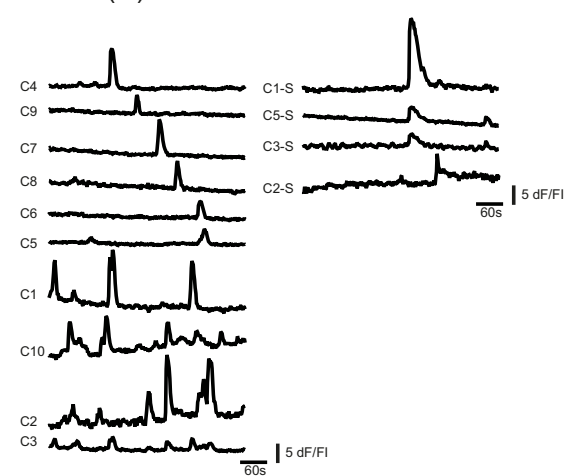

G
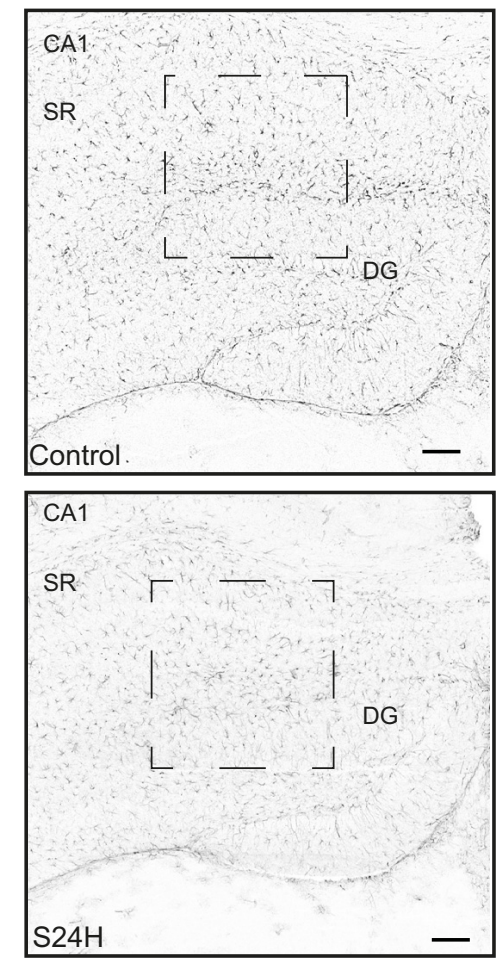

Figure 3. Resting calcium signaling is decreased in the hippocampal astrocytic network after surgery. $A$, Representative hippocampal slice from a control animal loaded with the astrocytic marker S101 (red) and the calcium dye 0GB-1M (green) and the corresponding overlay (yellow). B, A frame of a time-lapse imaging from the same slice in $\boldsymbol{A}$ with the active cells highlighted by a yellow circle. C, Traces of calcium spontaneous activity of the astrocytes outlined in C (from a control animal; left) and from a surgery-treated animal $24 \mathrm{~h}$ postsurgery (S24H; right). D, Twenty-four hours after surgery there is a decrease in the number of $\mathrm{S} 101+$ cells $\left({ }^{* *} p=0.002\right.$; unpaired $t$ test; $n=19-14$ slices). $\boldsymbol{E}-\mathbf{G}$, Hippocampal GFAP immunohistochemistry shows similar number of GFAP ${ }^{+}$cells between control and surgery-treated animals $(n=8-10$ animals; $\boldsymbol{E})$ but profound decrease in GFAP immunoreactivity after surgery $\left(\boldsymbol{F}, \boldsymbol{G} ;{ }^{* *} p=0.0019 ;\right.$ unpaired $t$ test; $n=6-9$ animals $)$. $\boldsymbol{H}$, The distribution of the percentage of active astrocytes is reduced after surgery ( $\# \# \equiv=0.0001$, unpaired $t$ test Welch's correction; $F$ test to compare variances; $F=10.36 ; D F n=18 ; D f d=13 ; n=$ $14-19$ slices). $I$, At $24 \mathrm{~h}$ postsurgery the frequency of the spontaneous ( ${ }^{*} p=0.01$; unpaired $t$ test with Welch's correction; $n=19-14$ slices; $4-5$ animals/group) and $(\boldsymbol{J})$ ATP-evoked calcium spikes is decreased ( ${ }^{*} p=0.05$; unpaired $t$ test with Welch's correction; $n=10-15$ slice; 7 animals/group). All data are presented as the mean \pm SEM.

and $72 \mathrm{~h}$ for GLUT-3 (Fig. $4 C$, bottom; ${ }^{* *} p=0.001$, S24H vs C; $n=5$ /group; ${ }^{* *} p=0.002, \mathrm{~S} 72 \mathrm{H}$ vs $\mathrm{C} ; n=5-15$ animals; one-way ANOVA, Fisher's multiple-comparisons test).

Finally, we analyzed the main brain lactate transporters, monocarboxylate transporters (MCTs) 1, 2, and 4, being MCT1 and MCT4 expressed in astrocytes and MCT-2 in neurons. MCT1 was significantly decreased at $6 \mathrm{~h}$, normal at $24 \mathrm{~h}$, and decreased at $72 \mathrm{~h}$ (Fig. $4 D$, top; ${ }^{\star} p=0.05 \mathrm{~S} 6 \mathrm{H}$ vs $\mathrm{C}$; $n=6-15$ animals; ${ }^{\star} p=0.032$, S72Hvs $C ; n=5-15$ animals; one-way ANOVA, Fisher's multiple-comparisons test); MCT2 was significantly decreased at $72 \mathrm{~h}$ (Fig. $4 D$, top; ${ }^{\star} p=0.042, \mathrm{~S} 72 \mathrm{H}$ vs $\mathrm{C} ; n=$
5-15 animals; one-way ANOVA, Fisher's multiple-comparisons test), and MCT4 dramatically increased at $24 \mathrm{~h}$ (Fig. $4 D ;{ }^{\star * * *} p<$ 0.0001 , S24H vs C; $n=5-14$ animals; one-way ANOVA, Fisher's multiple-comparisons test). Western blot analysis of hippocampal homogenates did not revealed any alteration in any of the brain lactate transporters tested (Fig. 4D, bottom, E).

Peripheral surgery affects hippocampal proteins involved in glutamate metabolism

In addition to their role in neuronal energy supply, astrocytes are also vital cell elements in the reuptake and recycling of glutamate 
A

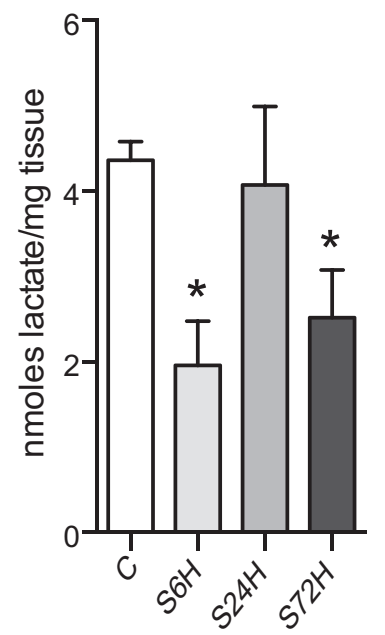

D
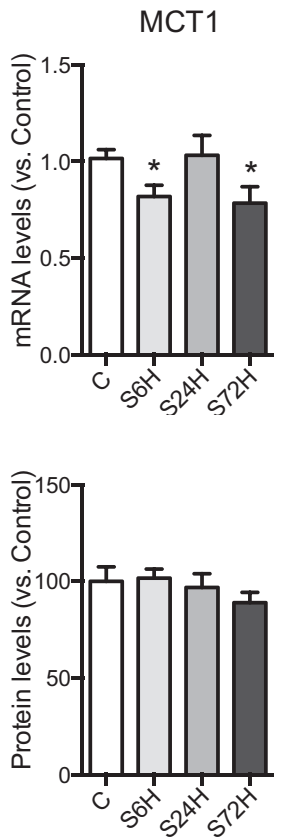

B

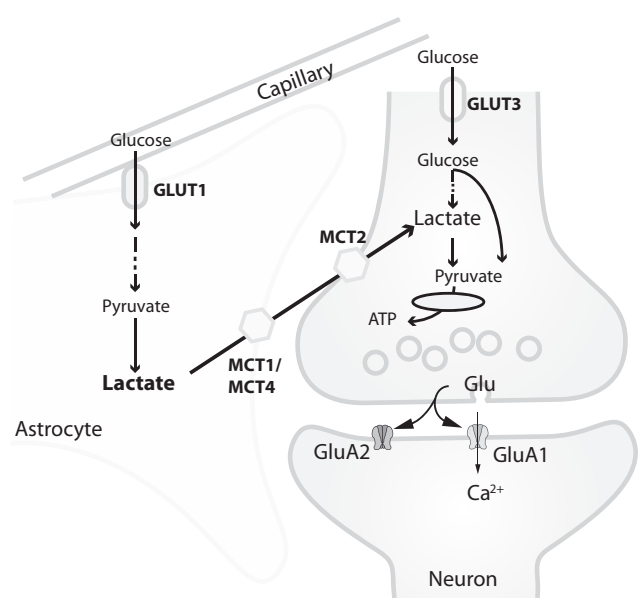

MCT2
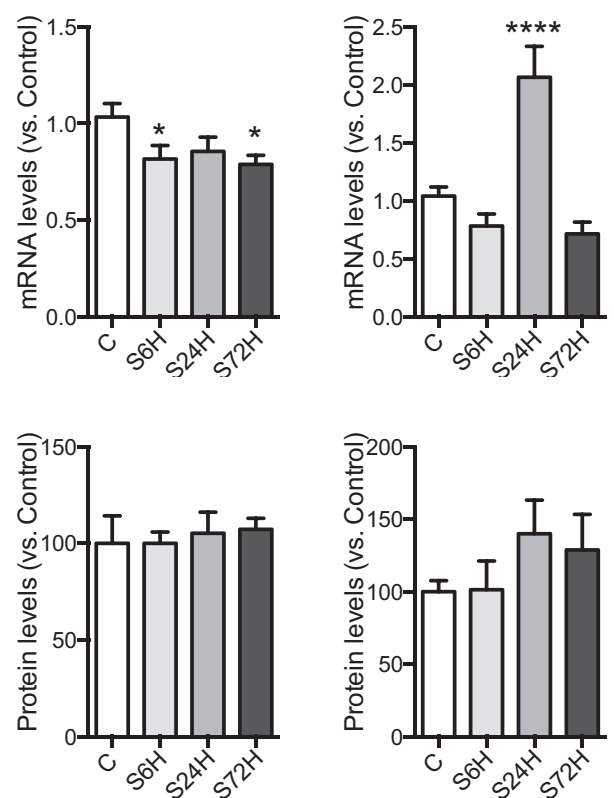

C
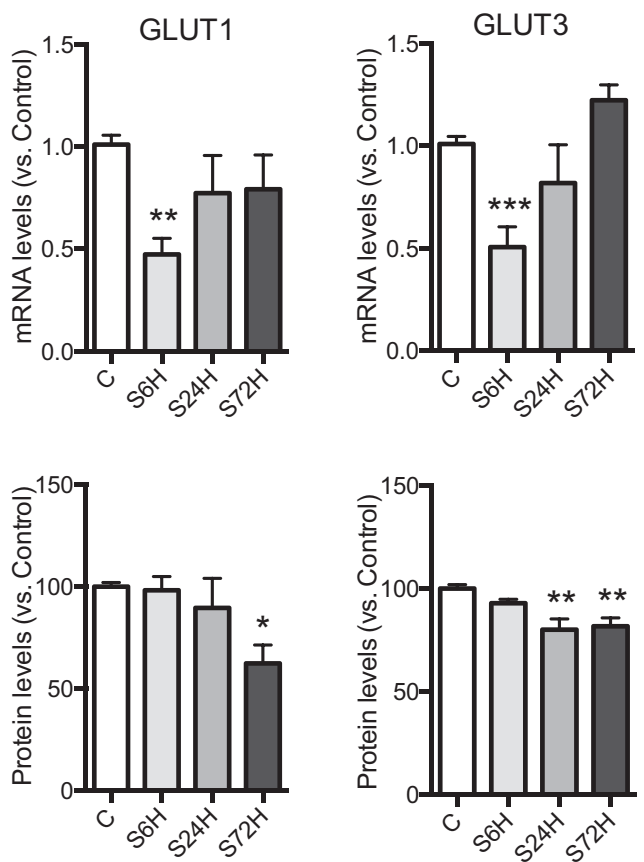

E

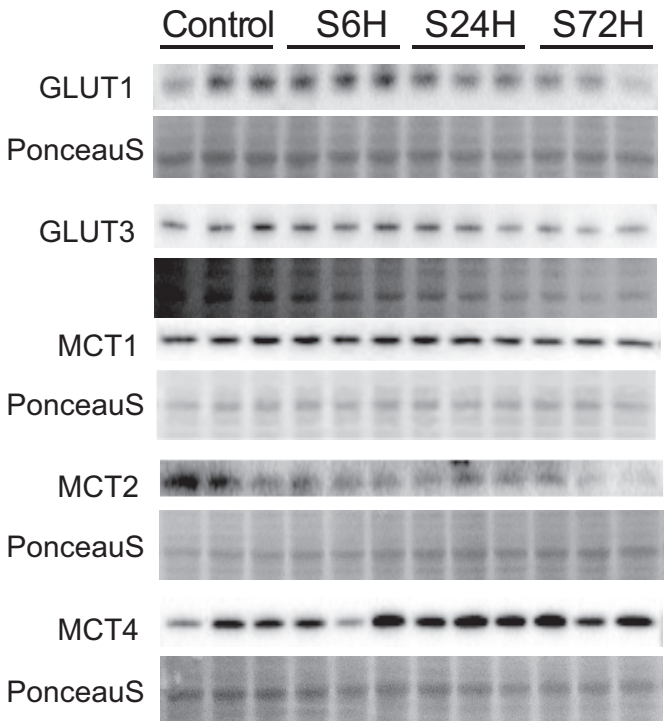

Figure 4. Glucose and lactate transporters deficiency is accompanied with changes in hippocampal lactate levels after peripheral surgery. $\boldsymbol{A}$, Schematic diagram of the astrocyte-neuron lactate shuttle. $\boldsymbol{B}$, Lactate levels in the whole hippocampal homogenates are decreased at 6 and $72 \mathrm{~h}$ postsurgery $\left({ }^{*} p=0.01\right.$, C vs S6H and ${ }^{*} p=0.047, \mathrm{C}$ vs $\mathrm{S72H} ;$ one-way ANOVA, Fisher's multiplecomparison test; $n=5$ mice/ group). C, Astrocyte glucose transporter GLUT1 and neuronal GLUT3 mRNA expression is decreased at $6 \mathrm{~h}$ postsurgery (Glut-1: ${ }^{* *} p=0.031 ;$ Glut-3: ${ }^{* *} p<0.0022$ one-way ANOVA, Fisher's multiple-comparison test; $n=5-15$ mice/group). Protein levels were decreased at $72 \mathrm{~h}$ after surgery for GLUT- $1\left({ }^{*} p=0.019, \mathrm{~S} 72 \mathrm{H}\right.$ vs $\left.\mathrm{C} ; n=5 \mathrm{mice} / \mathrm{group}\right)$ and decreased at 24 and $72 \mathrm{~h}$ for GLUT-3 $\left({ }^{* *} p=0.001, \mathrm{~S} 24 \mathrm{H}\right.$ vs $\mathrm{C} ;{ }^{* *} p=0.002, \mathrm{~S} 72 \mathrm{H}$ vs $\mathrm{C} ; n=5 \mathrm{mice} / \mathrm{group}$ ). $\boldsymbol{D}$, Monocarboxylate transporters mRNA expression is also affected after surgery (MCT1: ${ }^{*} p=0.05$ C vs S6H, ${ }^{*} p=0.032$ C vs S72H; MCT2: $p=0.054$ C vs $6 \mathrm{H} ;{ }^{*} p=0.042$ C vs S72H; MCT4: ${ }^{* * * *} p<0.0001$ ( vs S72H; one-way ANOVA, Fisher's multiple-comparison test; $n=5-15$ mice/group). $\boldsymbol{E}$, Corresponding protein blots for each protein (normalized to Ponceau S). Triplicates in each group represent different animals. All data are presented as the mean \pm SEM.

in the synapse. Through glutamate transporters (GLAST and GLT-1), astrocytes regulate glutamate release in the synapse by converting glutamate to glutamine through the glutamine synthase (GS) pathway, before releasing it to the extracellular space via glutaminases (GLS1). The released glutamine is subsequently taken up by neurons and reused as substrate for glutamate pro- duction to replenish the presynaptic neurotransmitter pool and help to maintain synaptic transmission (Fig. 5A).

We analyzed the mRNA and protein levels of the enzymes involved in the glutamate-glutamine cycling, such as GLAST, GLT-1, GS, and GLS1 at several time points after peripheral surgery. 
A

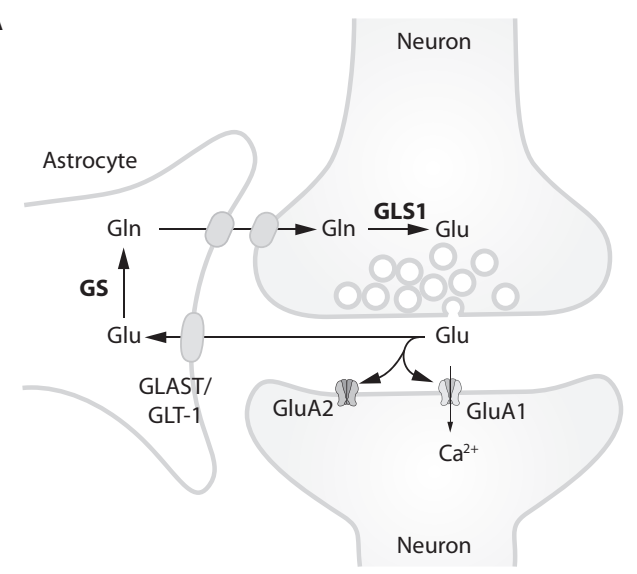

C

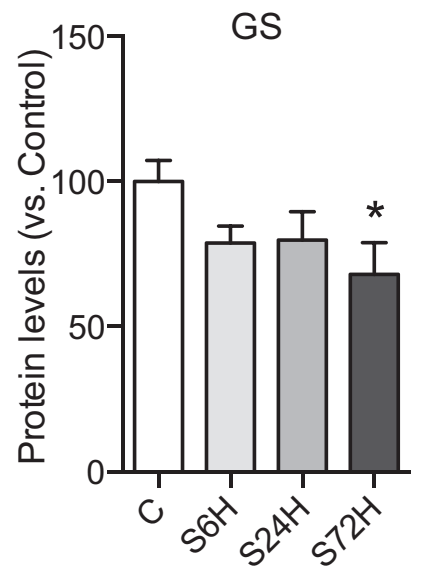

B

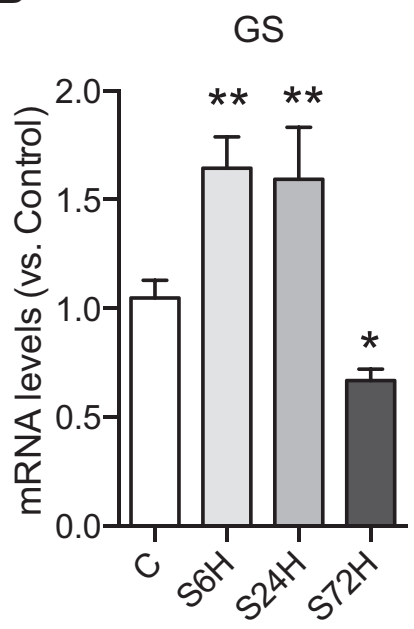

GLS1

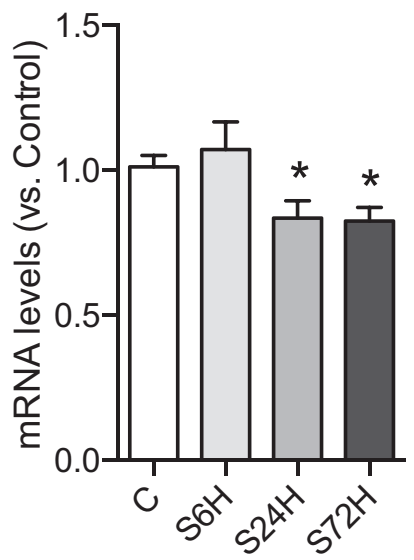

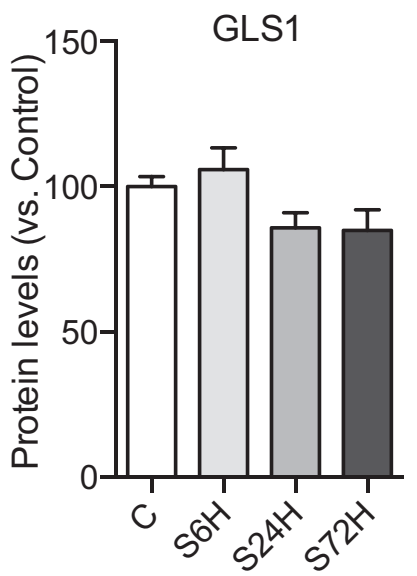

D

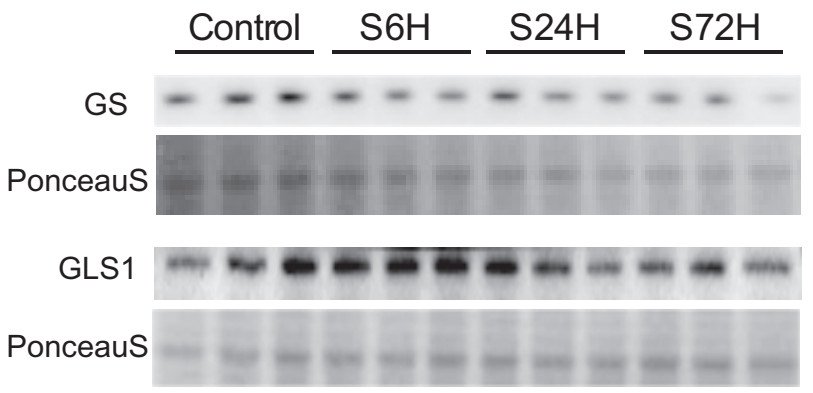

Figure 5. Peripheral surgery affects hippocampal enzymes involved in glutamate metabolism. $A$, Schematic illustration outlining the glutamate-glutamine cycle between astrocyte and neurons. $B$, Astrocyte GS and GLS1 mRNA expression and (C) protein levels $\left({ }^{*} p<0.05,{ }^{* *} p<0.01\right.$ vs C; one-way ANOVA, Fisher's multiple-comparison test; mRNA: $n=5-15$ mice/group; protein: $n=5$ mice/group). D, Corresponding protein blots for each protein (normalized to Ponceau S). Triplicates in each group represent different animals. All data are presented as the mean \pm SEM.

By quantitative real-time PCR we found a profound increase in the mRNA levels of the enzyme GS at 6 and $24 \mathrm{~h}$ (Fig. $5 B ;{ }^{* *} p=$ $0.001 ; \mathrm{S} 6 \mathrm{H}$ vs $\mathrm{C} ; n=6-15$ animals; ${ }^{* *} p=0.005 ; \mathrm{S} 24 \mathrm{H}$ vs $\mathrm{C} ; n=$ 5-15 animals; one-way ANOVA, Fisher's multiple-comparisons test) followed by a drastic reduction at $72 \mathrm{~h}$ postsurgery $\left({ }^{*} p=\right.$ 0.04, S72H vs C; $n=5-15$ animals; one-way ANOVA, Fisher's multiple-comparisons test). Similarly, we found a reduction in protein at $72 \mathrm{~h}$ postsurgery (Fig. $5 C, D,{ }^{*} p=0.019, \mathrm{~S} 72 \mathrm{H}$ vs $\mathrm{C} ; n=$ 5 animals/group). Gene expression of gls1 showed a decrease at 24 and $72 \mathrm{~h}$ after surgery (Fig. $5 B ;{ }^{*} p=0.01, \mathrm{~S} 24 \mathrm{H} \mathrm{vs} \mathrm{C} ;{ }^{*} p=0.02$, $\mathrm{S} 72 \mathrm{H}$ vs C; 5-15 animals; one-way ANOVA, Fisher's multiplecomparisons test), although no changes at the protein level were detected (Fig. 5C,D).

Functional and structural neuronal synaptic changes occur in the hippocampus at $72 \mathrm{~h}$ postsurgery

To further explore how tibia fracture affects the glutamatergic system we analyzed the proteins levels of the two most common subunits of the AMPA-Rs (GluA1 and GluA2) by Western blot. At $72 \mathrm{~h}$, we found a profound increase in the GluAl compared with controls (Fig. $6 \mathrm{~A}$, left, $C$; ${ }^{* *} p=0.004$; $\mathrm{C}$ vs $72 \mathrm{H} ; n=5-6$ animals; one-way ANOVA, Fisher's multiple-comparisons test) and a reduction in the GluA2 subunit (Fig. $6 A$, right, $C{ }^{*} p=0.01$;
C vs $\mathrm{S} 72 \mathrm{H} ; n=5-6$ animals; one-way ANOVA, Fisher's multiplecomparisons test).

In addition, we analyzed the glial glutamate transporters, GLAST and GLT-1, at the same time points ( 24 and $72 \mathrm{~h}$ postsurgery). At $72 \mathrm{~h}$, we found a reduction in the protein GLAST (Fig. 6B, left, $C$; ${ }^{* *} p=0.0017$; $\mathrm{C}$ vs $72 \mathrm{H} ; n=5-6$ animals; one-way ANOVA, Fisher's multiple-comparisons test) but no changes in GLT-1 (Fig. $6 B$, right, $C ; p=0.9 ; n=5-6$ animals one-way ANOVA, Fisher's multiple-comparisons test).

In addition to its role in glutamate recycling, GLAST plays an essential role in terminating synaptic transmission and maintaining safety levels of extracellular glutamate, because excessive amounts of glutamate would cause excitotoxicity via glutamate receptors (Fig. 6D). Similarly, alterations in AMPA-Rs subunit composition and reduced GLAST have been associated with increased glutamatergic transmission (Gómez-Galán et al., 2013, 2016). We finally investigated neuronal synaptic transmission after peripheral trauma by whole-cell patch-clamp recordings from CA1 pyramidal cells measuring spontaneous EPSCs (sEPSCs) at 24 and $72 \mathrm{~h}$ postsurgery. Although at $24 \mathrm{~h}$, the frequency (Fig. $6 E$, top; Hz: $1.5 \pm 0.2$ vs $2 \pm 0.3$; C vs S $24 \mathrm{H}$; unpaired $t$ test; $t=1.025$, $\mathrm{df}=24 ; p=0.3 ; n=8-18$ cells; $4-6$ animals/group) and the amplitude (Fig. $6 E$, bottom; pA: $18.5 \pm 0.6$ vs $18.5 \pm 0.6$; C vs 
A

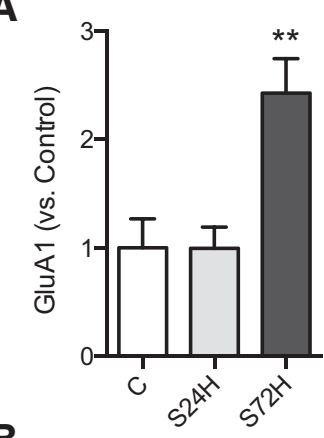

B
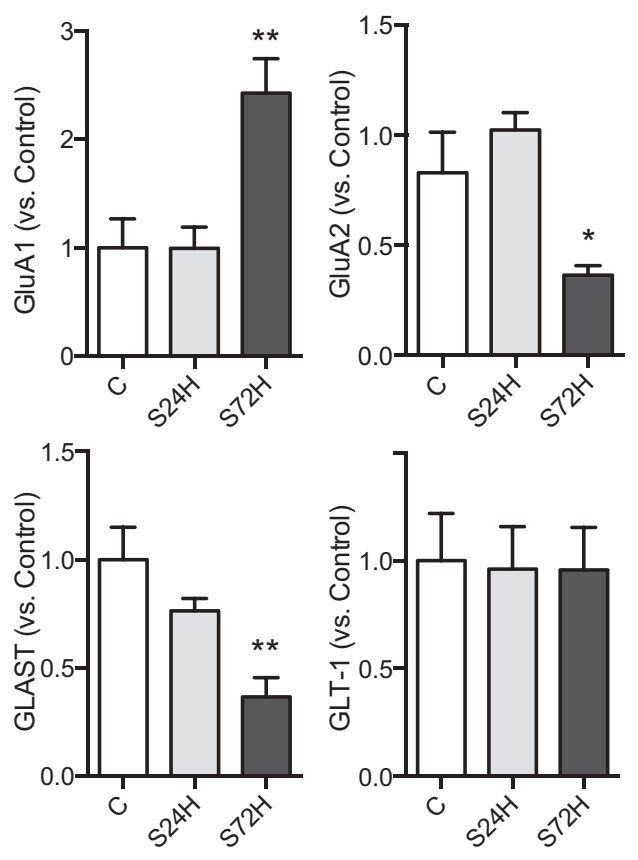

C

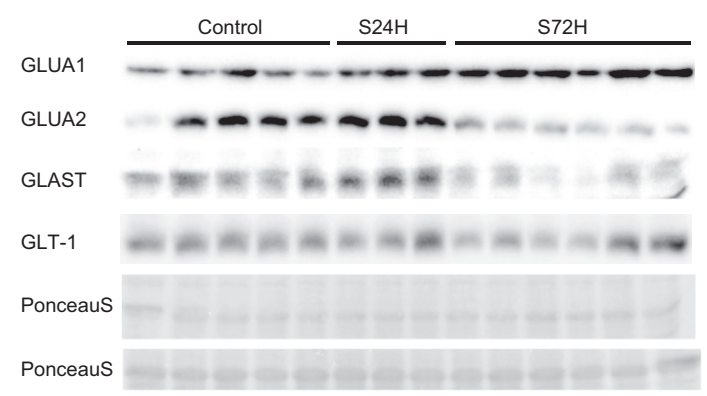

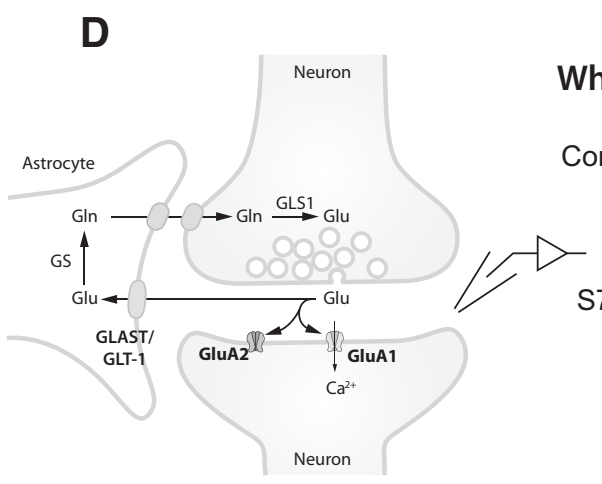

Whole-cell recording

Control

$\mathrm{S} 72 \mathrm{H}$

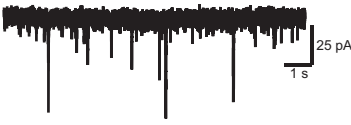
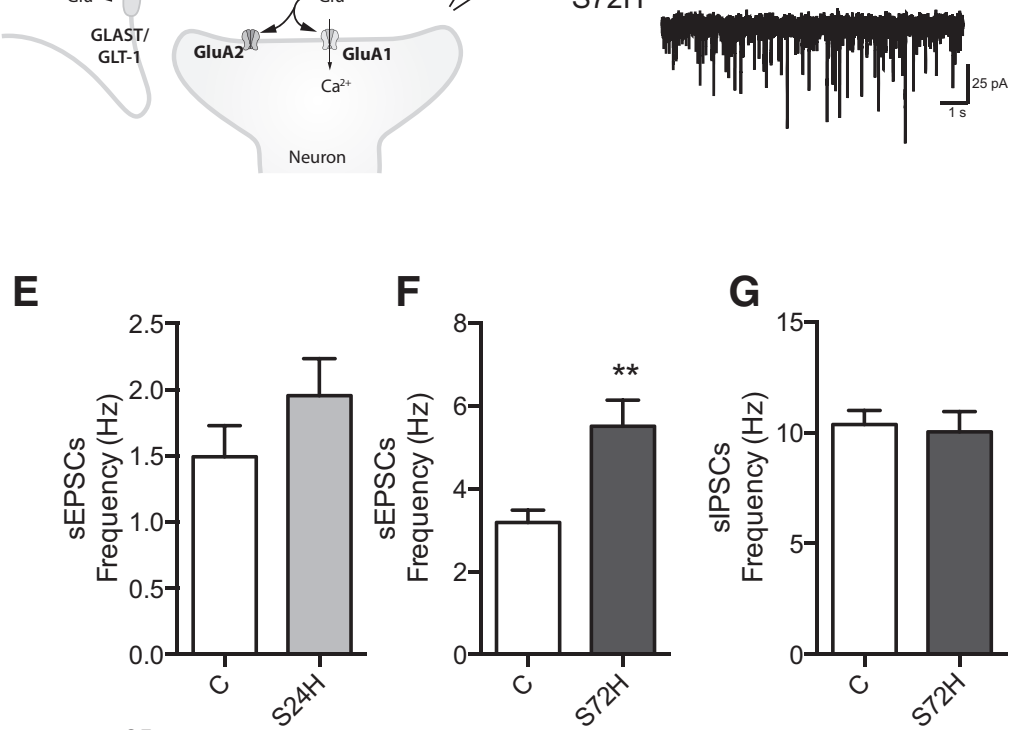

$\mathbf{F}$
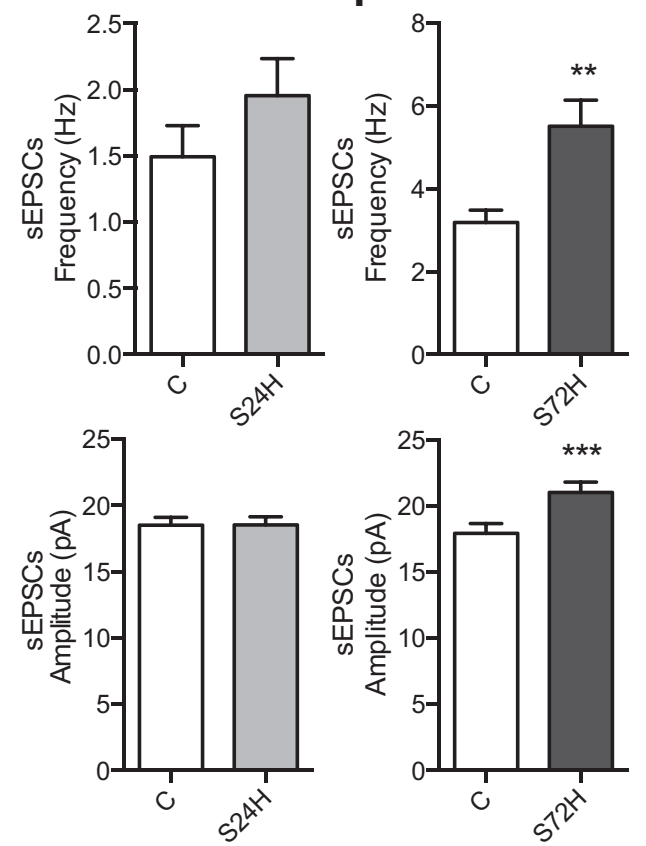

G
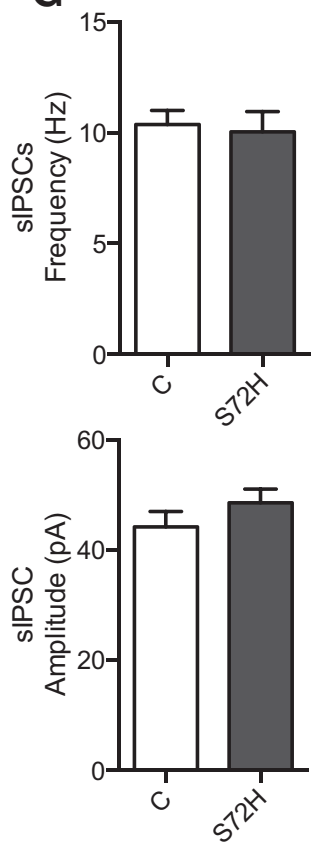

Figure 6. Functional and structural neuronal synaptic changes occur in the hippocampus at $72 \mathrm{~h}$ postsurgery. $A$, AMPA receptor subunits GluA1 and GluA2 are affected at $72 \mathrm{~h}$ postsurgery (left, GLUA1: ${ }^{* *} p=0.0017$ ( vs S72H; right, GLUA2: ${ }^{*} p=0.01$ (vs S72H; one-way ANOVA, Fisher's multiple-comparison test; $n=3-6$ animals/group). $B$, GLAST is downregulated at $72 \mathrm{~h}$ postsurgery (left, GLAST: ${ }^{* *} p=0.0017$ c vs S72H; one-way ANOVA, Fisher's multiple-comparison test; $n=3-6$ animals/group) but not effect is observed in GLT-1 (right). C, Representative blots of individual hippocampal samples from control, 24 and $72 \mathrm{~h}$ surgery-treated mice of the two most common subunits of the AMPARs (GLUR1 and GLUR2) and the astrocytic glutamate transporters (GLAST and GLT-1; normalized to the transfer Ponceau S). D, Schematic illustration outlining the neuronal glutamate synapse (left) and the representative examples of whole-cell patch-clamp recordings from a CA1 pyramidal cell from control (top right) and surgery-treated mouse $72 \mathrm{~h}$ postsurgery (bottom right). $\boldsymbol{E}$, At $24 \mathrm{~h}$ the frequency (top) and amplitude (bottom) remains normal ( $n=8-18$ cells; $4-6$ animals/group). $F$, At $72 \mathrm{~h}$ postsurgery the frequency (top) and amplitude (bottom) of sEPSCs is increased in the CA1 area of surgery-treated mice $(* * p=0.002, t$ test; $n=22-26$ cells; $7-11$ animals/group). G, The inhibitory (GABA) system remains unaffected at $72 \mathrm{~h}$ postsurgery ( $n=9-13$ cells; 3 animals/group). All data are presented as the mean \pm SEM.

S24H; unpaired $t$ test; $t=00013, \mathrm{df}=24 ; p=0.99 ; n=8-18$ cells; $4-6$ animals/group) of the sEPSCs events were similar to control animals, at $72 \mathrm{~h}$ we detected an increase in both the frequency (Fig. $6 F$, top; $\mathrm{Hz}: 3.2 \pm 0.3$ vs $5.5 \pm 0.6$; $\mathrm{C}$ vs $\mathrm{S} 72 \mathrm{H}$; unpaired $t$ test; $t=3.319, \mathrm{df}=35.22 ;{ }^{* *} p=0.002 ; n=22-26$ cells; 7 animals/group) and amplitude (Fig. $6 F$, bottom; pA: $17.9 \pm 0.7$ vs $21 \pm 0.8 ; \mathrm{C}$ vs S72H; unpaired $t$ test; $t=2.848$, $\mathrm{df}=$ $46 ;{ }^{* *} p=0.007 ; n=22-26$ cells; 7 animals/group) of sEPSCs compared with control, reflecting an increase in glutamatergic transmission. This increase in excitability may suggest an imbalance between the glutamatergic and the GABAergic (inhibitory) system. To rule out this hypothesis we analyzed spontaneous IPSCs (sIPSCs) from CA1 pyramidal cells at $72 \mathrm{~h}$. We did not find any difference between control and surgery-treated animals (Fig. $6 G$; frequency: $p=0.79$; amplitude: $p=0.27 ; t$ test; $n=9-13$ cells; 3 animals/group).

\section{Discussion}

The overarching aim of the present study was to determine the underlying temporal alterations associated with systemic immune activation after peripheral surgery on brain neuronal-glial function within hippocampal neuronal circuits of relevance for cognitive processing. Here, we uncover a series of astrocyte and neuronal metabolic, structural, and physiological changes in the hippocampus, which reinforce the idea of a dynamic peripheralto-brain communication and emphasize the role of astrocytes as key intermediaries between peripheral immune events and neuronal processing of information and cognition (Fig. 7).

Previous studies have identified a transient disruption of the $\mathrm{BBB}$ mediated by the proinflammatory milieu after surgery. Through a permeable BBB, cytokines and inflammatory mediators, such as macrophages, were shown to migrate into the hippocampus 

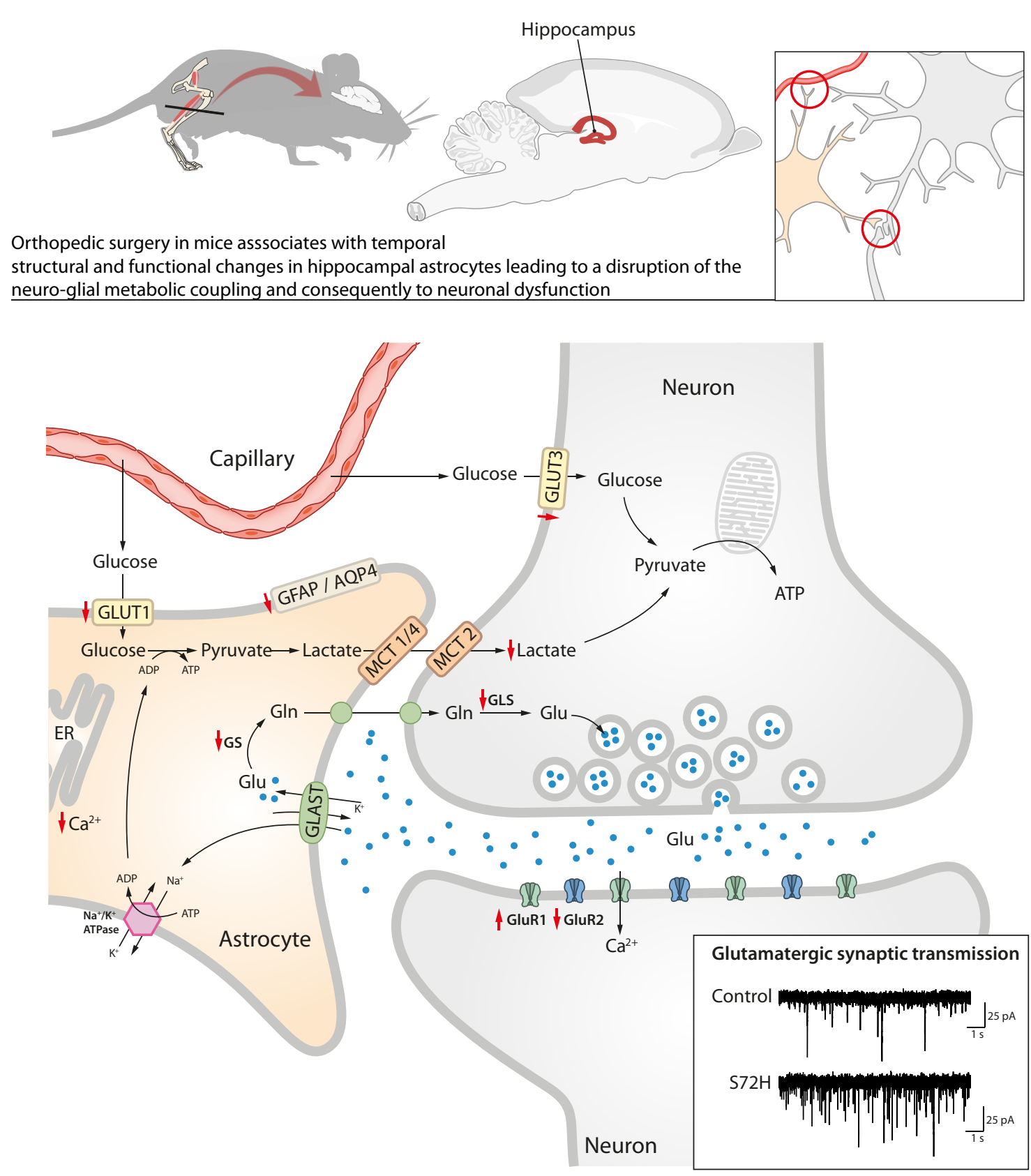

Hours

Days

Figure 7. Schematic illustration summarizing the effect of orthopedic mice surgery on hippocampal astrocyte-neuron metabolism, structure, and function. Orthopedic surgery in mice (i.e., tibia fracture) temporally orchestrates a series of hippocampal metabolic, structural, and functional changes first in the astrocyte and later in neurons that emphasize the role of astrocytes as key intermediaries between peripheral immune events and neuronal processing information and potentially to cognition. Red arrows depict decreased mRNA/protein levels.

and modulate its function contributing to postoperative cognitive decline (Terrando et al., 2011; Degos et al., 2013; Yang et al., 2017). These studies also found increased hippocampal mRNA expression of IL- $1 \beta$ and IL- 6 at 6 h postsurgery, which is in line with the presence of the proinflammatory cytokine IL- 6 protein in the hippocampus, suggesting that hippocampal inflammation may contribute to the mechanisms responsible for postoperative cognitive changes. Similarly, clinical studies have reported an increase in cytokines levels, including IL-6, in the CSF of patients after non-neurological surgery (Buvanendran et al., 2006; Bromander et al., 2012; Hirsch et al., 2016).
Astrocytes are critical components of the neurovascular unit, which is a key interface between the periphery and CNS (Kisler et al., 2017). They express cell-surface receptors for most cytokines, including IL-1 $\beta$ and IL-6 (Lovatt et al., 2007; Cahoy et al., 2008) and several studies have shown that astrocytes respond to cytokines and inflammatory mediators by altering their morphology and transcriptome profiles, including those related with structural proteins and $\mathrm{Ca}^{2+}$ signaling (Hamby et al., 2012; Zamanian et al., 2012; Sofroniew, 2014). Here we detected a decrease gene expression of the astrocyte markers GFAP and AQP4 accompanied with profound decrease in GFAP immunoreactivity and al- 
terations in the resting $\mathrm{Ca}^{2+}$ signaling at $24 \mathrm{~h}$ postsurgery. GFAP is an intermediate filament protein involved in the structure and function of the astrocyte's cytoskeleton whose expression is known to be essential for BBB integrity (Liedtke et al., 1996). Similarly, AQP4 is typically coexpressed with GFAP in astrocytes where it is highly polarized to astrocytic end-feet in close contact with blood vessels (Verkman et al., 2006) and participates in BBB formation (Nicchia et al., 2004; Blixt et al., 2015). Although the mechanisms related to BBB integrity after peripheral trauma was not the focus of the study, these new findings together with our previous observation of reduced hippocampal GFAP coverage in astrocytes (Terrando et al., 2013) support previous observation of surgery-induced BBB disruption at $24 \mathrm{~h}$ post-trauma (Terrando et al., 2011).

The reduction in GFAP and AQP4 expression and GFAP coverage observed after surgery may significantly affect astrocytes function, therefore disrupting neuronal circuits involved in higher brain functions, including cognition. Spontaneous or ligandevoked changes in intracellular $\mathrm{Ca}^{2+}$ concentration represent a form of astrocyte excitability that can enable astrocytes to modulate neuronal activity and behavior (Perea et al., 2009; Halassa and Haydon, 2010; Henneberger and Rusakov, 2010). Here, we found reduced astrocytic resting $\mathrm{Ca}^{2+}$ signaling evidenced by a reduction in the percentage of active cells within slices and lower $\mathrm{Ca}^{2+}$ signal frequency at $24 \mathrm{~h}$ post-trauma. Opposite to our findings, $\mathrm{Ca}^{2+}$ imaging studies from animal models of some brain pathologies, including stroke (Takatsuru et al., 2013), epilepsy (Ding et al., 2007), and AD (Abramov et al., 2003; Kuchibhotla et al., 2009) have shown enhanced astrocytic $\mathrm{Ca}^{2+}$ excitability. Although the mechanisms underlying this increase may differ among these pathologies, a common feature between them, and a difference with our model, is the presence of reactive astrocytes, including upregulation of GFAP and hypertrophy (Fedele et al., 2005; Osborn et al., 2016; Sims and Yew, 2017). We believe it is possible that some of the aspects related to the mechanisms involved in $\mathrm{Ca}^{2+}$ regulation in astrocytes may depend on the origin of the insult or even on the stage of the disorder.

Interesting, studies performed in the hippocampus of a triple transgenic mouse model of AD showed early (at 6 months old) reduction in GFAP surface and volume accompanied by a reduction of the glial branching, which progressed with age. Conversely, astrocytes surrounding amyloid plaques presented the typical reactive characteristics with thick processes and enlarged cell bodies (Olabarria et al., 2010). It would be interesting to apply this model to investigate whether such morphological changes also correlate with opposing changes in $\mathrm{Ca}^{2+}$ signaling. Notably, functional studies in these animals have shown synaptic plasticity and long-term memory deficits preceding the appearance of amyloid plaques and tangles (Oddo et al., 2003a,b).

Alterations in intracellular $\mathrm{Ca}^{2+}$ signaling after surgery may affect the release of gliotransmitters from astrocytes, including glutamate, ATP, D-serine, and GABA with the potential to generate a wide range of functional alterations related to synaptic transmission and plasticity (Parpura et al., 1994; Zonta et al., 2003). In addition, $\mathrm{Ca}^{2+}$ evoked release of messengers from astrocytes has also been suggested to regulated the energy supply to the brain (Wang et al., 2009; Bazargani and Attwell, 2016). Here, together with the functional changes observed in astrocytes, we found distinct temporal hippocampal alterations in glucose and glutamate signaling accompanied with changes in whole lactate levels at several time points after peripheral trauma suggesting a neuroglial metabolic uncoupling in the hippocampus. Lactate is produced by astrocytes via non-oxidative glucose utilization and shuttled to neurons via MCTs where it is used as an energy substrate (Allaman et al., 2011). The early decrease in the gene expression of the two main glucose transporters in the brain (GLUT 1-astrocyte and GLUT 3-neuron) accompanied with a reduction in hippocampal lactate levels points to an early alteration in the mechanisms responsible for the uptake of glucose by both, astrocytes and neurons. Interestingly, at $24 \mathrm{~h}$ postsurgery and coinciding with normal lactate levels, the MCT4, a transporter exclusively located in astrocytes and highly involved in lactate efflux to neurons (Pierre and Pellerin, 2005), shows a transient but profound upregulation. Supported by the astrocyte-neuron lactate shuttle hypothesis proposed by Pellerin and Magistretti (1994) (but see Magistretti, 2009; Barros and Deitmer, 2010), in which lactate release and concomitant glucose uptake in astrocytes is stimulated by sodium-coupled uptake of glutamate from glutamate transporters, we suggest that in our model this temporal upregulation in astrocytic lactate signaling at $24 \mathrm{~h}$ postsurgery followed by a decline in lactate levels at $72 \mathrm{~h}$ may indicate a failed protective attempt from astrocytes to provide with the energy requirements necessary to maintain neuronal activity and the associated brain functions, such as cognition.

The functional significance of lactate for cognition after surgery is further supported by other findings showing that interference with lactate transport from astrocytes into neurons impairs synaptic plasticity and memory (Newman et al., 2011; Suzuki et al., 2011).

Indeed, parallel to the synaptic plasticity and cognitive dysfunction previously reported (Terrando et al., 2013), at $72 \mathrm{~h}$ postsurgery we observed the main protein machinery involved in the control of glutamate neurotransmission and energy metabolism (performed by astrocytes) downregulated, including the glial glutamate (GLAST) and glucose (GLUT-1) transporters, but also the enzymes involved in the glutamate-glutamine cycle, such as GS and GLS1. In addition, the increased neuronal glutamatergic transmission here described at $72 \mathrm{~h}$ postsurgery in form of increase sEPSCs frequency and amplitude may be the functional consequence of the above mentioned alterations in the reuptake and recycling of glutamate by the astrocyte further accompanied by neuronal alterations in AMPA receptor subunit composition (GluA1 vs GluA2). Association between decreased GLAST protein levels and increased sEPSCs and impaired synaptic plasticity have also been reported in a rat model of depression characterized with astrocytic morphology alterations and cognitive deficits (Gómez-Galán et al., 2013). Notably, 5 weeks of social isolation in these rats also downregulated the protein levels of the GluA2 subunit of AMPA receptors (Gómez-Galán et al., 2016). In the hippocampus, the ability of $\mathrm{Ca}^{2+}$ to enter the neuronal cell through the AMPA receptor is determined by the GluA1 subunit, which is highly permeable to $\mathrm{Ca}^{2+}$ (Cull-Candy et al., 2006). Indeed, it has been shown that activation of GluA2-lacking receptors induces a retrograde signal that enhances release probability at the presynaptic terminal (Lindskog et al., 2010). Other studies have shown increased excitability and impaired synaptic plasticity and memory associated with changes in $\mathrm{Ca}^{2+}$-permeable AMPA receptors (Cull-Candy et al., 2006). Thus, in this surgical model a reduction of GluA2 may increase the probability of glutamate release that together with the reduction in glutamate uptake by the astrocyte, will contribute to increased levels of extracellular glutamate and to a concomitant increase in glutamate transmission. Because astrocytes do also express AMPA receptors further studies are necessary to address whether peripheral surgery affect differently glial and neuronal AMPA-R subunit composition and function. 
In summary, we demonstrate that peripheral surgery following systemic immune activation orchestrates temporal metabolic adaptations in the hippocampus, including alteration in glucose and glutamate signaling in astrocytes, and reduction in brain lactate availability. As a consequence, the neuroglial metabolic coupling is compromised as well as the astrocyte and neuronal function suggesting that the decrease in lactate availability in the hippocampus after peripheral trauma might be related to the cognitive impairment observed acutely after trauma.

\section{References}

Abramov AY, Canevari L, Duchen MR (2003) Changes in intracellular calcium and glutathione in astrocytes as the primary mechanism of amyloid neurotoxicity. J Neurosci 23:5088-5095. Medline

Allaman I, Bélanger M, Magistretti PJ (2011) Astrocyte-neuron metabolic relationships: for better and for worse. Trends Neurosci 34:76-87. CrossRef Medline

Banks WA (2005) Blood-brain barrier transport of cytokines: a mechanism for neuropathology. Curr Pharm Des 11:973-984. CrossRef Medline

Banks WA, Kastin AJ, Gutierrez EG (1994) Penetration of interleukin-6 across the murine blood-brain barrier. Neurosci Lett 179:53-56. CrossRef Medline

Banks WA, Kastin AJ, Broadwell RD (1995) Passage of cytokines across the blood-brain barrier. Neuroimmunomodulation 2:241-248. CrossRef Medline

Barros LF, Deitmer JW (2010) Glucose and lactate supply to the synapse. Brain Res Rev 63:149-159. CrossRef Medline

Bazargani N, Attwell D (2016) Astrocyte calcium signaling: the third wave. Nat Neurosci 19:182-189. CrossRef Medline

Beloosesky Y, Hendel D, Weiss A, Hershkovitz A, Grinblat J, Pirotsky A, Barak V (2007) Cytokines and C-reactive protein production in hipfracture-operated elderly patients. J Gerontol A Biol Sci Med Sci 62:420426. CrossRef Medline

Birch AM, Katsouri L, Sastre M (2014) Modulation of inflammation in transgenic models of Alzheimer's disease. J Neuroinflammation 11:25. CrossRef Medline

Blixt J, Svensson M, Gunnarson E, Wanecek M (2015) Aquaporins and blood-brain barrier permeability in early edema development after traumatic brain injury. Brain Res 1611:18-28. CrossRef Medline

Bromander S, Anckarsäter R, Kristiansson M, Blennow K, Zetterberg H, Anckarsäter H, Wass CE (2012) Changes in serum and cerebrospinal fluid cytokines in response to non-neurological surgery: an observational study. J Neuroinflammation 9:242. CrossRef Medline

Buvanendran A, Kroin JS, Berger RA, Hallab NJ, Saha C, Negrescu C, Moric M, Caicedo MS, Tuman KJ (2006) Upregulation of prostaglandin E2 and interleukins in the central nervous system and peripheral tissue during and after surgery in humans. Anesthesiology 104:403-410. CrossRef Medline

Cahoy JD, Emery B, Kaushal A, Foo LC, Zamanian JL, Christopherson KS, Xing Y, Lubischer JL, Krieg PA, Krupenko SA, Thompson WJ, Barres BA (2008) A transcriptome database for astrocytes, neurons, and oligodendrocytes: a new resource for understanding brain development and function. J Neurosci 28:264-278. CrossRef Medline

Cibelli M, Fidalgo AR, Terrando N, Ma D, Monaco C, Feldmann M, Takata M, Lever IJ, Nanchahal J, Fanselow MS, Maze M (2010) Role of interleukin- $1 \beta$ in postoperative cognitive dysfunction. Ann Neurol 68:360-368. CrossRef Medline

Collins LM, Toulouse A, Connor TJ, Nolan YM (2012) Contributions of central and systemic inflammation to the pathophysiology of Parkinson's disease. Neuropharmacology 62:2154-2168. CrossRef Medline

Cull-Candy S, Kelly L, Farrant M (2006) Regulation of Ca2+-permeable AMPA receptors: synaptic plasticity and beyond. Curr Opin Neurobiol 16:288-297. CrossRef Medline

Degos V, Vacas S, Han Z, van Rooijen N, Gressens P, Su H, Young WL, Maze M (2013) Depletion of bone marrow-derived macrophages perturbs the innate immune response to surgery and reduces postoperative memory dysfunction. Anesthesiology 118:527-536. CrossRef Medline

Ding S, Fellin T, Zhu Y, Lee SY, Auberson YP, Meaney DF, Coulter DA, Carmignoto G, Haydon PG (2007) Enhanced astrocytic $\mathrm{Ca}^{2+}$ signals contribute to neuronal excitotoxicity after status epilepticus. J Neurosci 27:10674-10684. CrossRef Medline
Fedele DE, Gouder N, Güttinger M, Gabernet L, Scheurer L, Rülicke T, Crestani F, Boison D (2005) Astrogliosis in epilepsy leads to overexpression of adenosine kinase, resulting in seizure aggravation. Brain 128:23832395. CrossRef Medline

Fidalgo AR, Cibelli M, White JP, Nagy I, Maze M, Ma D (2011) Systemic inflammation enhances surgery-induced cognitive dysfunction in mice. Neuroscience letters 498:63-66. CrossRef Medline

Forsberg A, Cervenka S, Jonsson Fagerlund M, Rasmussen LS, Zetterberg H, Erlandsson Harris H, Stridh P, Christensson E, Granström A, Schening A, Dymmel K, Knave N, Terrando N, Maze M, Borg J, Varrone A, Halldin C, Blennow K, Farde L, Eriksson LI (2017) The immune response of the human brain to abdominal surgery. Ann Neurol 81:572-582. CrossRef Medline

Gómez-Galán M, De Bundel D, Van Eeckhaut A, Smolders I, Lindskog M (2013) Dysfunctional astrocytic regulation of glutamate transmission in a rat model of depression. Mol Psychiatry 18:582-594. CrossRef Medline

Gómez-Galán M, Femenía T, Åberg E, Graae L, Van Eeckhaut A, Smolders I, Brené S, Lindskog M (2016) Running opposes the effects of social isolation on synaptic plasticity and transmission in a rat model of depression. PLoS One 11:e0165071. CrossRef Medline

Gutierrez EG, Banks WA, Kastin AJ (1994) Blood-borne interleukin-1 receptor antagonist crosses the blood-brain barrier. J Neuroimmunol 55: 153-160. CrossRef Medline

Halassa MM, Haydon PG (2010) Integrated brain circuits: astrocytic networks modulate neuronal activity and behavior. Annu Rev Physiol 72: 335-355. CrossRef Medline

Hamby ME, Coppola G, Ao Y, Geschwind DH, Khakh BS, Sofroniew MV (2012) Inflammatory mediators alter the astrocyte transcriptome and calcium signaling elicited by multiple G-protein-coupled receptors. J Neurosci 32:14489-14510. CrossRef Medline

Henneberger C, Rusakov DA (2010) Synaptic plasticity and Ca2+ signalling in astrocytes. Neuron Glia Biol 6:141-146. CrossRef Medline

Hill RA, Grutzendler J (2014) In vivo imaging of oligodendrocytes with sulforhodamine 101. Nat methods 11:1081-1082. CrossRef Medline

Hirsch J, Vacas S, Terrando N, Yuan M, Sands LP, Kramer J, Bozic K, Maze MM, Leung JM (2016) Perioperative cerebrospinal fluid and plasma inflammatory markers after orthopedic surgery. J Neuroinflammation 13: 211. CrossRef Medline

Kafitz KW, Meier SD, Stephan J, Rose CR (2008) Developmental profile and properties of sulforhodamine 101-labeled glial cells in acute brain slices of rat hippocampus. J Neurosci Methods 169:84-92. CrossRef Medline

Kisler K, Nelson AR, Montagne A, Zlokovic BV (2017) Cerebral blood flow regulation and neurovascular dysfunction in Alzheimer disease. Nat reviews Neuroscience 18:419-434. CrossRef Medline

Kline R, Wong E, Haile M, Didehvar S, Farber S, Sacks A, Pirraglia E, de Leon MJ, Bekker A (2016) Peri-operative inflammatory cytokines in plasma of the elderly correlate in prospective study with postoperative changes in cognitive test scores. Int J Anesthesiol Res 4:313-321. CrossRef Medline

Kuchibhotla KV, Lattarulo CR, Hyman BT, Bacskai BJ (2009) Synchronous hyperactivity and intercellular calcium waves in astrocytes in Alzheimer mice. Science 323:1211-1215. CrossRef Medline

Lebson L, Nash K, Kamath S, Herber D, Carty N, Lee DC, Li Q, Szekeres K, Jinwal U, Koren J, Dickey CA, Gottschall PE, Morgan D, Gordon MN (2010) Trafficking CD11b-positive blood cells deliver therapeutic genes to the brain of amyloid-depositing transgenic mice. J Neurosci 30:96519658. CrossRef Medline

Liedtke W, Edelmann W, Bieri PL, Chiu FC, Cowan NJ, Kucherlapati R, Raine CS (1996) GFAP is necessary for the integrity of CNS white matter architecture and long-term maintenance of myelination. Neuron 17:607615. CrossRef Medline

Lindskog M, Li L, Groth RD, Poburko D, Thiagarajan TC, Han X, Tsien RW (2010) Postsynaptic GluA1 enables acute retrograde enhancement of presynaptic function to coordinate adaptation to synaptic inactivity. Proc Natl Acad Sci U S A 107:21806-21811. CrossRef Medline

Lovatt D, Sonnewald U, Waagepetersen HS, Schousboe A, He W, Lin JH, Han X, Takano T, Wang S, Sim FJ, Goldman SA, Nedergaard M (2007) The transcriptome and metabolic gene signature of protoplasmic astrocytes in the adult murine cortex. J Neurosci 27:12255-12266. CrossRef Medline

Lu SM, Yu CJ, Liu YH, Dong HQ, Zhang X, Zhang SS, Hu LQ, Zhang F, Qian YN, Gui B (2015) S100A8 contributes to postoperative cognitive dysfunction in mice undergoing tibial fracture surgery by activating the 
TLR4/MyD88 pathway. Brain Behav Immun 44:221-234. CrossRef Medline

Magistretti PJ (2009) Role of glutamate in neuron-glia metabolic coupling. Am J Clin Nutr 90:875S-880S. CrossRef Medline

Newman LA, Korol DL, Gold PE (2011) Lactate produced by glycogenolysis in astrocytes regulates memory processing. PloS one 6:e28427. CrossRef Medline

Nicchia GP, Nico B, Camassa LM, Mola MG, Loh N, Dermietzel R, Spray DC, Svelto M, Frigeri A (2004) The role of aquaporin-4 in the blood-brain barrier development and integrity: studies in animal and cell culture models. Neuroscience 129:935-945. CrossRef Medline

Oddo S, Caccamo A, Kitazawa M, Tseng BP, LaFerla FM (2003a) Amyloid deposition precedes tangle formation in a triple transgenic model of Alzheimer's disease. Neurobiol Aging 24:1063-1070. CrossRef Medline

Oddo S, Caccamo A, Shepherd JD, Murphy MP, Golde TE, Kayed R, Metherate R, Mattson MP, Akbari Y, LaFerla FM (2003b) Triple-transgenic model of Alzheimer's disease with plaques and tangles: intracellular $\mathrm{A} \beta$ and synaptic dysfunction. Neuron 39:409-421. CrossRef Medline

Olabarria M, Noristani HN, Verkhratsky A, Rodríguez JJ (2010) Concomitant astroglial atrophy and astrogliosis in a triple transgenic animal model of Alzheimer's disease. Glia 58:831-838. Medline

Osborn LM, Kamphuis W, Wadman WJ, Hol EM (2016) Astrogliosis: an integral player in the pathogenesis of Alzheimer's disease. Prog Neurobiol 144:121-141. CrossRef Medline

Parpura V, Basarsky TA, Liu F, Jeftinija K, Jeftinija S, Haydon PG (1994) Glutamate-mediated astrocyte-neuron signalling. Nature 369:744-747. CrossRef Medline

Pellerin L, Magistretti PJ (1994) Glutamate uptake into astrocytes stimulates aerobic glycolysis: a mechanism coupling neuronal activity to glucose utilization. Proc Natl Acad Sci U S A 91:10625-10629. CrossRef Medline

Perea G, Navarrete M, Araque A (2009) Tripartite synapses: astrocytes process and control synaptic information. Trends Neurosci 32:421-431. CrossRef Medline

Perry VH, Holmes C (2014) Microglial priming in neurodegenerative disease. Nat Rev Neurol 10:217-224. CrossRef Medline

Perry VH, Newman TA, Cunningham C (2003) The impact of systemic infection on the progression of neurodegenerative disease. Nat Rev Neurosci 4:103-112. CrossRef Medline

Perry VH, Cunningham C, Holmes C (2007) Systemic infections and inflammation affect chronic neurodegeneration. Nat Rev Immunol 7:161167. CrossRef Medline

Pierre K, Pellerin L (2005) Monocarboxylate transporters in the central nervous system: distribution, regulation and function. J Neurochem 94:1-14. CrossRef Medline

Romero-Calvo I, Ocón B, Martínez-Moya P, Suárez MD, Zarzuelo A, Martínez-Augustin O, de Medina FS (2010) Reversible Ponceau staining as a loading control alternative to actin in Western blots. Anal Biochem 401:318-320. CrossRef Medline

Rosczyk HA, Sparkman NL, Johnson RW (2008) Neuroinflammation and cognitive function in aged mice following minor surgery. Exp Gerontol 43:840-846. CrossRef Medline

Saederup N, Cardona AE, Croft K, Mizutani M, Cotleur AC, Tsou CL, Ran- sohoff RM, Charo IF (2010) Selective chemokine receptor usage by central nervous system myeloid cells in CCR2-red fluorescent protein knock-in mice. PLoS One 5:e13693. CrossRef Medline

Schindelin J, Arganda-Carreras I, Frise E, Kaynig V, Longair M, Pietzsch T, Preibisch S, Rueden C, Saalfeld S, Schmid B, Tinevez JY, White DJ, Hartenstein V, Eliceiri K, Tomancak P, Cardona A (2012) Fiji: an opensource platform for biological-image analysis. Nat Methods 9:676-682. CrossRef Medline

Sims NR, Yew WP (2017) Reactive astrogliosis in stroke: contributions of astrocytes to recovery of neurological function. Neurochem Int 107:88 103. CrossRef Medline

Sofroniew MV (2014) Multiple roles for astrocytes as effectors of cytokines and inflammatory mediators. Neuroscientist 20:160-172. CrossRef Medline

Suzuki A, Stern SA, Bozdagi O, Huntley GW, Walker RH, Magistretti PJ, Alberini CM (2011) Astrocyte-neuron lactate transport is required for long-term memory formation. Cell 144:810-823. CrossRef Medline

Takatsuru Y, Eto K, Kaneko R, Masuda H, Shimokawa N, Koibuchi N, Nabekura J (2013) Critical role of the astrocyte for functional remodeling in contralateral hemisphere of somatosensory cortex after stroke. J Neurosci 33:4683-4692. CrossRef Medline

Terrando N, Monaco C, Ma D, Foxwell BM, Feldmann M, Maze M (2010) Tumor necrosis factor-alpha triggers a cytokine cascade yielding postoperative cognitive decline. Proc Natl Acad Sci U S A 107:20518-20522. CrossRef Medline

Terrando N, Eriksson LI, Ryu JK, Yang T, Monaco C, Feldmann M, Jonsson Fagerlund M, Charo IF, Akassoglou K, Maze M (2011) Resolving postoperative neuroinflammation and cognitive decline. Ann Neurol 70:986995. CrossRef Medline

Terrando N, Gómez-Galán M, Yang T, Carlström M, Gustavsson D, Harding RE, Lindskog M, Eriksson LI (2013) Aspirin-triggered resolvin D1 prevents surgery-induced cognitive decline. FASEB J 27:3564-3571. CrossRef Medline

Thévenaz P, Ruttimann UE, Unser M (1998) A pyramid approach to subpixel registration based on intensity. IEEE Trans Image Process 7:27-41. CrossRef Medline

Verkman AS, Binder DK, Bloch O, Auguste K, Papadopoulos MC (2006) Three distinct roles of aquaporin-4 in brain function revealed by knockout mice. Biochim Biophys Acta 1758:1085-1093. CrossRef Medline

Wang X, Takano T, Nedergaard M (2009) Astrocytic calcium signaling: mechanism and implications for functional brain imaging. Methods Mol Biol 489:93-109. CrossRef Medline

Yang S, Gu C, Mandeville ET, Dong Y, Esposito E, Zhang Y, Yang G, Shen Y, Fu X, Lo EH, Xie Z (2017) Anesthesia and surgery impair blood-brain barrier and cognitive function in mice. Front Immunol 8:902. CrossRef Medline

Zamanian JL, Xu L, Foo LC, Nouri N, Zhou L, Giffard RG, Barres BA (2012) Genomic analysis of reactive astrogliosis. J Neurosci 32:6391-6410. CrossRef Medline

Zonta M, Sebelin A, Gobbo S, Fellin T, Pozzan T, Carmignoto G (2003) Glutamate-mediated cytosolic calcium oscillations regulate a pulsatile prostaglandin release from cultured rat astrocytes. J Physiol 553:407-414. CrossRef Medline 